\title{
Genetic Determinants of Antibiotic Resistance in Francisella
}

\author{
Stephen J. Kassinger and Monique L. van Hoek* \\ School of Systems Biology, George Mason University, Manassas, VA, United States
}

Tularemia, caused by Francisella tularensis, is endemic to the northern hemisphere. This zoonotic organism has historically been developed into a biological weapon. For this Tier 1, Category A select agent, it is important to expand our understanding of its mechanisms of antibiotic resistance (AMR). Francisella is unlike many Gramnegative organisms in that it does not have significant plasmid mobility, and does not express AMR mechanisms on plasmids; thus plasmid-mediated resistance does not occur naturally. It is possible to artificially introduce plasmids with AMR markers for cloning and gene expression purposes. In this review, we survey both the experimental research on AMR in Francisella and bioinformatic databases which contain genomic and proteomic data. We explore both the genetic determinants of intrinsic AMR and naturally acquired or engineered antimicrobial resistance as well as phenotypic resistance in Francisella. Herein we survey resistance to beta-lactams, monobactams, carbapenems,

\section{OPEN ACCESS}

Edited by:

Eleftherios Mylonakis, Warren Alpert Medical School of Brown University, United States

Reviewed by: Joseph Horzempa, West Liberty University, United States Deanna Schmitt, West Liberty University, United States

*Correspondence: Monique L. van Hoek mvanhoek@gmu.edu

Specialty section: This article was submitted to Antimicrobials, Resistance and Chemotherapy, a section of the journal Frontiers in Microbiology

Received: 22 December 2020 Accepted: 25 March 2021

Published: 12 May 2021

Citation:

Kassinger SJ and van Hoek ML (2021) Genetic Determinants of Antibiotic Resistance in Francisella.

Front. Microbiol. 12:644855. doi: 10.3389/fmicb.2021.644855 aminoglycosides, tetracycline, polymyxins, macrolides, rifampin, fosmidomycin, and fluoroquinolones. We also highlight research about the phenotypic AMR difference between planktonic and biofilm Francisella. We discuss newly developed methods of testing antibiotics against Francisella which involve the intracellular nature of Francisella infection and may better reflect the eventual clinical outcomes for new antibiotic compounds. Understanding the genetically encoded determinants of AMR in Francisella is key to optimizing the treatment of patients and potentially developing new antimicrobials for this dangerous intracellular pathogen.

Keywords: antibiotic resistance, Francisella, tularemia, biofilm, multidrug resistance, antibiotic drug resistance

\section{INTRODUCTION}

Antibiotic resistance (AMR) is a significant and emerging threat to modern medicine. AMR, whether naturally acquired or engineered, is also of significant concern in the area of biodefense. In addition, bacteria that have a significant intracellular phase to their lifecycle or form biofilms pose inherent challenges to extracellular antibiotic treatment (phenotypic resistance). The possible emergence of naturally acquired or engineered AMR will only reduce the few therapeutic options available. In light of the emerging AMR crisis and the rapid emergence of antibiotic resistantbacteria in hospital and community settings, as well as in combat casualty care, it is critical to understand the genetic determinants of AMR.

Francisella tularensis is the causative agent of the zoonotic disease tularemia. It is a facultative intracellular bacterium, infecting and replicating within macrophages and other phagocytic cells as well as cells of the reticuloendothelial system in the host. It has been classified as a Tier 1 Category A select agent and a biothreat agent due to its low inhaled infectious dose $(>10$ organisms for humans) and its historical development as a biological weapon (Dennis et al., 2001). 
While the disease is relatively uncommon in the current times, outbreaks have become more frequent in recent years in the central United States and across northern Europe (Eliasson et al., 2002; Reintjes et al., 2002; Akal $l \mathrm{n}$ et al., 2009; Brett et al., 2014; Dupont et al., 2015; Zargar et al., 2015; Coates et al., 2018). Francisella is intrinsically resistant to many classes of antibiotics due to the nature of its LPS and the many enzymes it produces (Biswas et al., 2008; Caspar and Maurin, 2017). The facultative intracellular phase of its lifecycle provides additional challenges to systemic antibiotic therapy which can also lead to treatment failures. While no clinical samples have shown enhanced AMR over wild type strains (Urich and Petersen, 2008), this may be a result of the difficulty of isolating Francisella from clinical samples (Sutera et al., 2014b) as both the strain and the context of isolation seem to influence the cultivability of Francisella (Humrighouse et al., 2011). Nonetheless, several Francisella mutants have been isolated against a variety of clinically relevant antibiotics in vitro. The genetic determinants of resistance to these drugs are of interest (Munita and Arias, 2016). In recent years, many more strains and species of Francisella have been sequenced, enabling this review of the genetic determinants of AMR in Francisella and to update earlier summaries (Biswas et al., 2008).

Of critical interest are those drugs that are commonly used to treat patients with tularemia, as enhanced resistance to these would force the use of other less optimal antibiotics. Historically, aminoglycosides such as streptomycin and gentamicin are favored as treatments, followed by tetracyclines such as tetracycline and doxycycline, and more recently fluoroquinolones, such as ciprofloxacin (Dennis et al., 2001).

\section{ANTIBIOTICS EFFECTIVE AGAINST Francisella}

Antibiotics work by one of the five general mechanisms: they can (i) inhibit cell wall synthesis, (ii) depolarize the plasma membrane, (iii) inhibit protein synthesis, (iv) inhibit nucleic acid synthesis, or (v) inhibit metabolic pathways. Thus, AMR is usually the result of a genetic change that happens in the bacteria resulting in the ability of the bacteria to survive in the presence of the antibiotic (Reygaert, 2018). Genotypic resistance is therefore inheritable by definition, whereas phenotypic resistance is a change in gene expression that is not heritable. Epigenetics can also be involved in AMR in bacteria (Ghosh et al., 2020, \#1868), although this has not been well studied in Francisella. We will discuss both genotypic and phenotypic resistance for Francisella.

Research Question: What is the role of the epigenetics in antibiotic resistance in Francisella?

The antibiotics that are considered most effective against Francisella include streptomycin (intramuscular or intravenous), gentamicin (intravenous), doxycycline, tetracycline, and ciprofloxacin (Table 1) (Dennis et al., 2001). Recently, levofloxacin has also shown good results in animal studies (Klimpel et al., 2008; Nelson et al., 2010). Streptomycin and gentamicin are aminoglycoside antibiotics, which are protein synthesis inhibitors, and these two compounds are usually bactericidal. Doxycycline is a "tetracycline class" of antibiotic, and along with tetracycline, works by inhibiting protein synthesis. These antibiotics are usually bacteriostatic. The fluoroquinolone class, ciprofloxacin and levofloxacin, act on DNA Gyrase, thus inhibiting nucleic acid synthesis, and are both bactericidal (Caspar and Maurin, 2017).

New antimicrobials are being developed against Francisella by several researchers. One class being developed and tested is antimicrobial peptides, which depolarize the plasma membrane of Francisella, and may have additional pathogen-directed and host-directed effects as well (Han et al., 2008; Amer et al., 2010; Flick-Smith et al., 2013; Kaushal et al., 2016). Novel antibiotic compounds such as $N$-benzyl aminomethyl spectinomycins (Scarff et al., 2019) and arsinothricin (Nadar et al., 2019) have recently been developed or identified, potentially providing additional therapeutic options for tularemia.

\section{MECHANISMS OF ANTIBIOTIC RESISTANCE}

There are common mechanisms of AMR that are generally found in prokaryotes. These mechanisms include modification of the drug target, limiting the uptake of the drug, inactivation of the drug, and active efflux of the drug.

The bacterium, in response to treatment, can alter the protein sequence of the antibiotic target (Spratt, 1994). This is observed with rifampicin, an antibiotic that has a single known protein target, RpoB which is subject to mutation as a mechanism of resistance (Taniguchi et al., 1996) (see section "Rifampin Resistance"). In another mechanism, some bacteria indirectly interfere with the binding of drug to target protein by way of a blocker protein. This phenomenon is referred to as "target blocking" and while it has been known as a mechanism of resistance for tetracycline for many years (Manavathu et al., 1990), its greater distribution among drug resistances is now becoming more apparent (Wilson et al., 2020). Cells can also overproduce the antibiotic target, effectively overcoming the drug's inhibition. This is seen with the overproduction of the target protein dihydrofolate reductase in trimethoprim resistance (Huovinen, 2001).

Limitation of uptake of the drug is seen as a mechanism of resistance if the drug-entry into the bacterium is transporter-dependent. For example, we demonstrated that Francisella novicida can spontaneously become resistant to fosmidomycin via a mutation in the GlpT (glycerol-3-phosphate) transporter (Mackie et al., 2012), and further that use of a lipophilic prodrug of fosmidomycin can bypass this resistance (McKenney et al., 2012).

Other drug resistance mechanisms focus on the drugs themselves as opposed to the drug targets. A bacterium can destroy the drug as exemplified by penicillins being destroyed by $\beta$-lactamses (Majiduddin et al., 2002). A bacterium can also alter the drug such as with chloramphenicol-acetyl-transferase which reduces its activity (Shaw, 1975). More rarely, a bacterium can produce a binding partner for the drug which stochastically limits 
TABLE 1 | Intrinsic antibiotic resistance in Francisella.

\begin{tabular}{|c|c|c|c|}
\hline Antibiotic class & Drug name & Francisella response & References \\
\hline Beta lactam & Penicillin & Resistant & Caspar and Maurin, 2017 \\
\hline $\begin{array}{l}\text { Dihydrofolatereductase } \\
\text { inhibitors }\end{array}$ & $\begin{array}{l}\text { Sulfamethoxazole trimethoprim } \\
\text { (cotrimoxaole) }\end{array}$ & Resistant & Biswas et al., 2008 \\
\hline \multirow[t]{2}{*}{ Polymyxins } & Polymyxin B & Resistant & Caspar and Maurin, 2017 \\
\hline & Colistin (polymyxin E) & Resistant & Caspar and Maurin, 2017 \\
\hline Macrolides & Erythromycin & Sensitive/resistant (strain dependent) & Biswas et al., 2008 \\
\hline Macrolide & Azithromycin & Type B-Resistant, Type A-Sensitive & Ahmad et al., 2010 \\
\hline Carbapenems & Various & Sensitive/resistant (strain dependent) & $\begin{array}{l}\text { Tomaso et al., 2005; Hotta et al., 2013; } \\
\text { Caspar and Maurin, } 2017\end{array}$ \\
\hline Monobactam & Aztreonam & Sensitive/resistant (strain dependent) & $\begin{array}{l}\text { Scheel et al., 1993; Garcia del Blanco } \\
\text { et al., 2004; Tomaso et al., 2005; } \\
\text { Antunes et al., 2012; Dean and van } \\
\text { Hoek, 2015; Caspar and Maurin, 2017; } \\
\text { Hotta et al., } 2020\end{array}$ \\
\hline Cephalosporin & $\begin{array}{l}\text { Cefotaxime, moxalactam } \\
\text { (latamoxef), ceftazidime }\end{array}$ & Type A-sensitive, Type B-resistant & Baker et al., 1985; Tomaso et al., 2005 \\
\hline \multirow[t]{3}{*}{ Aminoglycosides } & $\begin{array}{l}\text { Streptomycin, gentamicin, } \\
\text { amikacin, tobramycin }\end{array}$ & Sensitive & Caspar and Maurin, 2017 \\
\hline & Kanamycin & Sensitive & Zogaj and Klose, 2010 \\
\hline & Hygromycin & Sensitive & Zogaj and Klose, 2010 \\
\hline Aminoglycoside-aminocyclitol & Spectinomycin & Sensitive & $\begin{array}{l}\text { Buchan et al., 2008; Zogaj and Klose, } \\
\text { 2010; Scarff et al., } 2019\end{array}$ \\
\hline Ansamycins (antimycobacterial) & Rifampicin & Sensitive & Caspar and Maurin, 2017 \\
\hline $\begin{array}{l}\text { DXR (1-deoxy-D-xylulose } \\
\text { 5-phosphate } \\
\text { reductoisomerase) inhibitors }\end{array}$ & Fosmidomycin, FR900098 & Sensitive & McKenney et al., 2012 \\
\hline \multicolumn{4}{|l|}{ Clinically used antibiotics } \\
\hline Aminoglycosides & Streptomycin, gentamicin & Sensitive & Caspar and Maurin, 2017 \\
\hline Tetracyclines & Tetracycline, doxycycline & Sensitive & Caspar and Maurin, 2017 \\
\hline Fluoroquinolones & Ciprofloxacin, levofloxacin & Sensitive & Caspar and Maurin, 2017 \\
\hline
\end{tabular}

This table is organized in approximate order of resistance from resistant to mixed to sensitive.

the influence of the drug such as the case with zeocin resistance and the ble gene (Drocourt et al., 1990).

Active efflux of the antibiotic via multidrug efflux pumps is another common mechanism of acquired resistance. This mechanism is commonly seen in Gram-negative pathogens including Acinetobacter, Burkholderia, and Pseudomonas (Kumar et al., 2008; Lee et al., 2017; Zahedi Bialvaei et al., 2021).

\section{PHENOTYPIC RESISTANCE}

Bacteria can exhibit phenotypic resistance to antibiotics based on the expression of a physical characteristic (such as biofilm) or through gaining access to a protected location (such as intracellular replication). Francisella employs both of these strategies to demonstrate phenotypic resistance.

A critical aspect in designing antibiotics to eradicate intracellular bacteria is to appreciate the protective effects of their intracellular localization. Francisella spp. can be taken up by macrophages, dendritic cells, and other phagocytic cells (Cowley et al., 1997; Golovliov et al., 1997; Bosio and Dow, 2005), as well as hepatocytes, lung epithelial cells, and even red blood cells (Conlan and North, 1992; Gentry et al., 2007; Hall et al., 2007; Schmitt et al., 2017) as a facultative intracellular pathogen.
The bacteria are able to use their Type VI secretion system (encoded on the Francisella Pathogenicity Island) to escape the phagosome and replicate in the cytosol of the eukaryotic host cell. In this location, the bacteria are phenotypically resistant to many antibiotics that cannot efficiently penetrate the eukaryotic membrane. This is the basis of the "gentamicin protection assay," for example, in which gentamicin is applied to the infected, cultured host cells, and the intracellular bacteria are unaffected by the antibiotic and can replicate (Isberg and Falkow, 1985). Any extracellular, un-phagocytized bacteria will be killed by the extracellular gentamicin antibiotic, enabling the measurement of intracellular replication (Isberg and Falkow, 1985). This intracellular residence is also thought to contribute to the fairly common relapses observed with bacteriostatic antibiotics such as tetracycline. Interestingly, this apparent "problem" of intracellular localization can also be put to use as a novel screening model to identify antibiotics that are able to affect the intracellular form of Francisella. Several of these approaches are summarized at the end of this review.

Francisella has been shown to form biofilms (Dean et al., 2009; Durham-Colleran et al., 2010; Margolis et al., 2010; Chung et al., 2014; Champion et al., 2019). Francisella embedded in these biofilms were shown to have increase AMR compared to planktonic cells (Biot et al., 2020; Siebert et al., 2020), similar 
to what has been observed with other bacteria (Singh et al., 2017). This is thought to be mainly due to poor diffusion of the antibiotics through the extracellular polysaccharide matrix that makes up the biofilm. It is not clear what role biofilms play in the Francisella lifecycle and/or human disease (van Hoek, 2013). The two-component system that regulates biofilm production (qseBC) is important for virulence, but biofilm is thought to contribute more to survival in Francisella's environmental niches (van Hoek, 2013). Additional mechanisms of bacterial resistance can contribute to the phenotypic resistance provided by the biofilm, including slow growth rate, induction of efflux pump expression, and induction of persister cells (Soto, 2013).

A third example of phenotypic AMR in Francisella is demonstrated by the temperature-dependent inhibition of gentamicin uptake at low temperatures (Loughman et al., 2016). This is discussed further in Section "Aminoglycoside Resistance".

\section{HORIZONTAL GENE TRANSFER IN Francisella}

Horizontal gene transfer commonly leads to the acquisition of antibiotic-resistance genes and gene-clusters by Gram-negative bacteria, such as Acinetobacter for example (Forsberg et al., 2012; Wang and Sun, 2015). There are three main mechanisms by which DNA transfer occurs in bacteria: bacterial conjugation, natural transformation, and transduction.

- Conjugation: Conjugation is the transfer of circular plasmid DNA from one bacterial cell to another through cell-cell contact. This method has been used in Francisella to enable the creation of mutants and to mobilize plasmids (Golovliov et al., 2003; Challacombe et al., 2017; Brodmann et al., 2018).

- Transformation: Transformation is the introduction of "free" DNA from the environment into a bacterium. In Francisella, transformation has been achieved by electroporation and chemical transformation methods, depending on the species (see below).

- Transduction: Transduction is the transfer of DNA to a bacterium via a bacteriophage. There have been only a few reports of bacteriophage which can act against Francisella so far (Koliaditskaia et al., 1959; Tlapak et al., 2018) and they appear so far to be unstable or difficult to isolate. This area of research is ongoing, but one very interesting finding was the identification of CRISPR/CAS9 system in F. novicida (Schunder et al., 2013), suggesting that there have been bacteriophage interactions with Francisella in the past, enough to acquire a viral immunity system such as CRISPR/Cas.

In addition to phage and transposons moving DNA, sometimes cells rearrange their DNA though minor failures of normal DNA replication maintenance machinery. The closely related members of the Francisella genus all exhibit significant rearrangement of their genomes with respect to each other, suggesting that this has occurred (Petrosino et al., 2006).

\section{PLASMIDS IN Francisella}

Francisella is unlike many Gram-negative organisms in that it does not appear to carry AMR or virulence genes on plasmids. Francisella does not easily acquire plasmids as very few plasmids are identified in isolates (Challacombe et al., 2017). Thus plasmidmediated acquired AMR does not appear to occur naturally (Challacombe et al., 2017). The few plasmids that have been identified within Francisella species do not encode very many proteins, and do not appear to confer any AMR (Pomerantsev et al., 2001a,b; Frank and Zahrt, 2007; Challacombe et al., 2017). Francisella cannot express exogenous Escherichia coli plasmids (McWhinnie and Nano, 2014) and require the use of Francisella promoters and specific codon optimization for highlevel plasmid-mediated protein expression (Sjostedt et al., 1990; Golovliov et al., 1997; Brodmann et al., 2018). Thus, it is possible to introduce antibiotic resistance on plasmids experimentally to Francisella species for selection during cloning using plasmids typically engineered from pFNL10 or another naturally occurring Francisella plasmids as the backbone (Ludu et al., 2008).

Methods of introduction of plasmids used in the laboratory for research purposes include electroporation (Baron et al., 1995) and cryotransformation (Pavlov et al., 1996; Lai et al., 2010) for F. tularensis, chemical competence for F. novicida (Anthony et al., 1991), and triparental conjugation for F. tularensis holarctica LVS (Golovliov et al., 2003; Horzempa et al., 2008) and F. novicida (Brodmann et al., 2018).

The antibiotics used for cloning must be those that are not clinically useful for the treatment of tularemia, such as kanamycin (Frank and Zahrt, 2007). The reasons for this are twofold: first, in the unlikely event a researcher contracts Francisella in laboratory, that infection can be treated via standard and established methods; and second, due to the historic development of Francisella as a biological weapon, creation of a strain resistant to clinically-useful antibiotics could be a violation of the ban on the development of biological weapons. Recently, a new plasmid was constructed to enable tetracycline-inducible proteinexpression system for Francisella by modifying the promoter to be a strong Francisella-specific promoter among other changes (Sheshko et al., 2021) despite tetracycline still being a clinically useful antibiotic for tularemia.

\section{INTRINSIC ANTIBIOTIC RESISTANCE IN Francisella}

Francisella is intrinsically resistant to many antibiotics (Table 1). This pattern of resistance is predominantly dependent on the genetic determinants of the strains and species, dependent on the expression of chromosomal genes. There are a few instances of phenotypic resistance, discussed above. A study using a comprehensive transposon-insertion library and a phenotype screen in F. novicida confirmed the presence of intrinsic antibioitic resistance genes, and identified some genes that were not previously known to be involved in AMR (Enstrom et al., 2012). For example, this study showed very similar antibiotic sensitivities of $a c r A / B$ and tolC mutants, suggesting 
that these proteins might work together in the resistance to multiple antibiotics.

While Francisella does not demonstrate acquired resistance due to mobile elements and horizontal transfer, such as occurs in many human pathogens, it is useful to recognize that this important biothreat pathogen is susceptible to only three major classes of antibiotics and exhibits resistance to many antibiotic classes.

\section{Beta-Lactam Resistance}

Penicillin is known to prevent the growth of many microorganisms (Fleming, 1929) and had been successfully used to treat human staphylococcal infections (Abraham et al., 1941). These results led to the solving of the structure of penicillin and closely related compounds (Chain, 1979) revealing the important structural similarity in the beta-lactam ring. A beta-lactam ring is a four-membered ring consisting of three carbons and a nitrogen with one of the carbons immediately adjacent to the nitrogen being double bonded to an oxygen (Bodey, 1990). Chemists then developed several synthetic derivatives based around the beta-lactam ring (Baldwin et al., 1973; Edwards et al., 1975). During this process, the target for beta-lactams was discovered to be bacterial cell wall synthesis (Strominger et al., 1959). With greater use of beta-lactams came a broader understanding of mechanisms of resistance (Knowles, 1985). Beta-lactam resistance generally is due to one of three different mechanisms: altering outer membrane permeability (LPS), altering the drugs target [penicillin-binding proteins (PBP)], or degrading the drug enzymatically (beta-lactamase) (Bodey, 1990).

Beta lactam antibiotics act against rapidly dividing bacteria by binding to penicillin-binding proteins, and thus inhibiting the bacterial cell wall synthesis. An examination of Francisella genomes using the KEGG database reveals four to five potential penicillin-binding protein encoding genes (Table 2), including PBP-3, PBP-4, and PBP5/6 members. Of this group, only one gene, DacD (FTN_0907), has been investigated in regard of beta lactam resistance and was shown not to be involved in beta lactam resistance (Spidlova et al., 2018). Interestingly, we have identified a penicillin-binding protein activator (LpoB) in all the Francisella genomes examined. This protein is an activator of PBP-1b's transpeptidase and transglycosylase activities in other organisms, and thus is a regulator of peptidoglycan synthesis. Its role in Francisella is unclear given the lack of PBP-1.

Research Question: What is the role of the multiple penicillin-binding proteins (PBPs) and the activator LpoB in beta-lactam resistance in Francisella?

Francisella, as a genus, is largely resistant to penicillins and monobactam antibiotics (Scheel et al., 1993; Ikaheimo et al., 2000). Yet the resistance to cephalosporins appears to be variable across the genus. One study reports Francisella strains (clinical samples mostly from the southeastern and southwestern areas of the United States) to be susceptible to third-generation cephalosporins such as cefotaxime, moxalactam (latamoxef), and ceftazidime (Baker et al., 1985), yet another study indicates largely the opposite when testing Biovar II strains of F. tularensis holarctica (Tomaso et al., 2005). The resistance to carbapenems also appears to be variable across strains tested (Tomaso et al., 2005; Hotta et al., 2013). These disparities between studies are well summarized by Caspar and Maurin (2017). Unfortunately, the strains comparison across studies is difficult as the nomenclature of Francisella has changed considerably over the years, and many strains are annotated only as F. tularensis. Other factors precluding direct comparison include different testing methods of AMR, such as non-CLSI standard minimum inhibitory concentration (MIC) testing (Heine et al., 2017) and E-strip testing and the use of multiple media with various supplementations.

Beta-lactamase enzymes generally are of two main groups: metallo-beta-lactamases and serine-beta-lactamases (bla genes) (Conlan and North, 1992). Analysis of the genome sequences reveals that most Francisella strains possessed a blaA ( $\beta$ lactamase class A) gene and a gene for ampG (Biswas et al., 2008). Amber class A $\beta$-lactamases are the most common betalactamase class found in bacteria resistant to $\beta$-lactam antibiotics. Metallo- $\beta$-lactamase family genes have not been identified in the Francisella genomes (Biswas et al., 2008). The known mechanisms of AMR to beta-lactams in F. tularensis revolve around two genes FTT_0681c and FTT_0611c, also known as bla1 and bla2 (or FTU-1) (Bina et al., 2006; Antunes et al., 2012). Bla2 is reported to be a non-carbapenem-hydrolyzing beta-lactamase which appears to be intrinsic in the genus and appears to confer a narrow-spectrum of resistance to beta-lactams, limited mainly to penicillins. This enzyme is classified as an Ambler Class A and Bush class $2 \mathrm{f}$ beta-lactamase (Juan et al., 2017).

The F. tularensis holarctica LVS equivalent gene of bla2 FTT_0611c (FTL_0879) was shown to be a functional betalactamase as its expression in E. coli increased the resistance of E. coli to penicillins, but not to third generation cephalosporins (Bina et al., 2006); thus, it is unlikely to be an extended-spectrum beta-lactamases (EBSL). Expression of FTT_0681c (FTL_0957) did not have the same effect. It was later shown that the protein product of FTT_0611c also acts as a very weak carbapenemase (Antunes et al., 2012; see section "Carbapenem Resistance"). Some Francisella strains also encode a third putative betalactamase gene FTT_0783, about which little is known beyond the fact that in LVS, FTL_1439 (equivalent to FTT_0783) appears to be more expressed at $26^{\circ} \mathrm{C}$ than $37^{\circ} \mathrm{C}$, as judged by copy number (Cross and Jacobs, 1993; Horzempa et al., 2008). There may be additional mechanisms involved in beta-lactam resistance beyond these beta-lactamase enzymes such as penicillin-binding proteins or changes in cell permeability.

AmpG proteins are peptide-glycan specific permeases that are membrane proteins and can transport drugs through the same pathway used by murein components (Biswas et al., 2008). They are also annotated as major facilitator superfamily (MFS) proteins. In E. coli, AmpG transduces the signal that induces expression of the AmpC beta-lactamase protein in response to beta-lactams. Thus, AmpG in E. coli acts as a permease in peptidoglycan recycling and in the beta-lactamase induction 
TABLE 2 | The annotated PBP gene in Francisella species and subspecies using KEGG database.

\begin{tabular}{|c|c|c|c|}
\hline & $\begin{array}{l}\text { Francisella tularensis subsp. } \\
\text { tularensis Schu S4 }\end{array}$ & $\begin{array}{l}\text { Francisella tularensis subsp. } \\
\text { holarctica LVS }\end{array}$ & $\begin{array}{l}\text { Francisella tularensis subsp. } \\
\text { novicida U112 }\end{array}$ \\
\hline & $\begin{array}{l}\text { Locus (KEGG orthology) name } \\
\text { [E.C. number], other information }\end{array}$ & $\begin{array}{l}\text { Locus (KEGG orthology) name } \\
\text { [E.C. number], other information }\end{array}$ & $\begin{array}{l}\text { Locus (KEGG orthology) name [E.C. } \\
\text { number], other information }\end{array}$ \\
\hline $\begin{array}{l}\text { Penicillin-binding protein } 3 \\
\text { (PBP-3) }\end{array}$ & $\begin{array}{l}\text { FTT_0697 (K03587) FtsI } \\
\text { Peptidoglycan } \\
\text { D,D-transpeptidase, cell division } \\
\text { protein FtsI (penicillin-binding } \\
\text { protein 3) [EC:3.4.16.4] ftsl; } \\
\text { peptidoglycan synthetase }\end{array}$ & $\begin{array}{l}\text { FTL_1539 (K03587) cell division } \\
\text { protein Ftsl (penicillin-binding } \\
\text { protein 3) [EC:3.4.16.4] } \\
\text { penicillin-binding protein } \\
\text { (peptidoglycan synthetase) }\end{array}$ & $\begin{array}{l}\text { FTN_0607 (K03587) cell division } \\
\text { protein FtsI (penicillin-binding protein } \\
\text { 3) [EC:3.4.16.4] ftsl; cell division } \\
\text { protein, peptidoglycan synthetase } \\
\text { (PBP) }\end{array}$ \\
\hline PBP-4 & $\begin{array}{l}\text { FT__1039 (K07259) serine-type } \\
\text { D-Ala-D-Ala } \\
\text { carboxypeptidase/endopeptidase } \\
\text { (penicillin-binding protein 4) } \\
\text { [EC:3.4.16.4 3.4.21.-] | dacB1; } \\
\text { D-alanyl-D-alanine } \\
\text { carboxypeptidase Uniprot } \\
\text { Q5NG20 }\end{array}$ & $\begin{array}{l}\text { FTL_1046 (K07259) Serine-type } \\
\text { D-Ala-D-Ala } \\
\text { carboxypeptidase/endopeptidase } \\
\text { (penicillin-binding protein 4) } \\
\text { [EC:3.4.16.4 3.4.21.-] } \\
\text { D-alanyl-D-alanine } \\
\text { carboxypeptidase } \\
\text { (Penicillin-binding protein) family } \\
\text { protein }\end{array}$ & $\begin{array}{l}\text { FTN_0917 (K07259) Serine-type } \\
\text { D-Ala-D-Ala } \\
\text { carboxypeptidase/endopeptidase } \\
\text { (penicillin-binding protein 4) } \\
\text { [EC:3.4.16.4 3.4.21.-] serine-type } \\
\text { D-Ala-D-Ala carboxypeptidase }\end{array}$ \\
\hline PBP-4 & No homolog found & $\begin{array}{l}\text { FTL_1509 D-alanyl-D-alanine } \\
\text { carboxypeptidase/D-alanyl-D- } \\
\text { alanine-endopeptidase }\end{array}$ & $\begin{array}{l}\text { FTN_0635 (K07259) serine-type } \\
\text { D-Ala-D-Ala } \\
\text { carboxypeptidase/endopeptidase } \\
\text { (penicillin-binding protein 4) } \\
\text { [EC:3.4.16.4 3.4.21.-] serine-type } \\
\text { D-Ala-D-Ala carboxypeptidase }\end{array}$ \\
\hline PBP-5/6 & $\begin{array}{l}\text { FT__1029 (K07258) dacD, } \\
\text { Serine-type D-Ala-D-Ala } \\
\text { carboxypeptidase } \\
\text { (penicillin-binding protein 5/6) } \\
\text { [EC:3.4.16.4] D-alanyl-D-alanine } \\
\text { carboxypeptidase }\end{array}$ & $\begin{array}{l}\text { FTL_1060 (K07258) serine-type } \\
\text { D-Ala-D-Ala carboxypeptidase } \\
\text { (penicillin-binding protein 5/6) } \\
\text { [EC:3.4.16.4] | (GenBank) } \\
\text { D-alanyl-D-alanine } \\
\text { carboxypeptidase } \\
\text { (penicillin-binding protein) family } \\
\text { protein }\end{array}$ & $\begin{array}{l}\text { FTN_0907 (K07258) serine-type } \\
\text { D-Ala-D-Ala carboxypeptidase } \\
\text { (penicillin-binding protein 5/6) } \\
\text { [EC:3.4.16.4] }\end{array}$ \\
\hline $\begin{array}{l}\text { Penicillin-binding protein } \\
\text { activator (LpoB) }\end{array}$ & $\begin{array}{l}\text { FT_1540c (K07337) } \\
\text { penicillin-binding protein activator } \\
\text { hypothetical protein }\end{array}$ & $\begin{array}{l}\text { FTL_0571 (K07337) } \\
\text { penicillin-binding protein activator, } \\
\text { conserved hypothetical protein }\end{array}$ & $\begin{array}{l}\text { FTN_1449 (K07337) penicillin-binding } \\
\text { protein activator, conserved protein of } \\
\text { unknown function }\end{array}$ \\
\hline
\end{tabular}

system (Lindquist et al., 1993; Schmidt et al., 1995). The role of AmpG in Francisella has not been studied, nor the inducibility of the beta-lactamases. In Francisella, one amp $G$ homolog gene has been identified in each of the major species (Table 3). Other components of this system in E. coli include AmpC, AmpR, AmpD, and AmpE. Of these, only AmpD ( $N$-acetylmuramoyl-Lalanine amidase) has been annotated in F. novicida (FTN_1551) and F. tularensis (FTT_0162).

Research Question: Is ampG expression inducible by beta-lactams and what is its role in beta-lactam resistance in Francisella?

\section{Monobactam Resistance}

Monobactams are specific class of beta-lactams that have beta-lactam rings that are not fused to other rings, unlike most other beta-lactams such as penicillin. They are resistant to enzymatic degradation by metallo-beta-lactamases, but are generally susceptible to degradation by serine beta-lactamases. These antibiotics are generally effective against aerobic, Gramnegative bacteria. The most common example of this class is Aztreonam. Francisella is generally considered to be resistant to monobactams through the same beta-lactamase genes as confer beta-lactam resistance (Caspar and Maurin, 2017). Resistance to aztreonam is reported in F. tularensis holarctica

TABLE 3 | Putative AmpG permease homologs (MFS protein) in Francisella (selected genes from Uniprot.org).

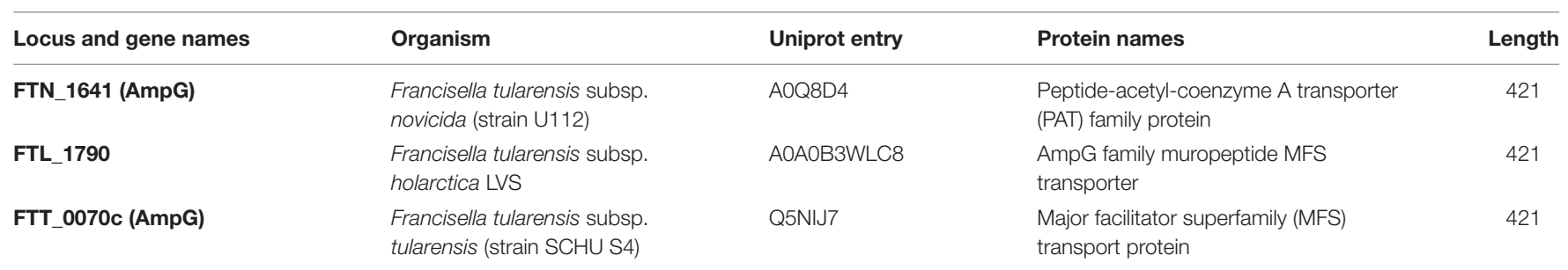


strains (Scheel et al., 1993; Garcia del Blanco et al., 2004; Tomaso et al., 2005). For Japanese strains of F. tularensis subsp. holarctica biovar japonica, the MIC is reported to range from 0.75 to $>256 \mu \mathrm{g} / \mathrm{mL}$ aztreonam (Hotta et al., 2020). Interestingly, it was found that aztreonam demonstrated a significant inhibition of biofilm formation for $F$. novicida (Dean and van Hoek, 2015). Recently, the class A $\beta$ lactamase gene FTU-1 in F. tularensis (see section "Carbapenem Resistance") was found to be unable to hydrolyze aztreonam (Antunes et al., 2012).

\section{Carbapenem Resistance}

Carbapenems are also members of the beta-lactam class of antibiotics. They consist of the classic beta-lactam ring fused at the nitrogen and a neighboring carbon to an additional ringed three carbons. Regarding the carbon immediately neighboring the nitrogen along the additional ring, there is a double bond (to the adjoining carbon) and a carboxylic acid. All other positions are variable. Due to this structure, carbapenems differ from beta-lactams such as penicillin in that they are not typically cleaved by beta-lactamases. Francisella as a genus has mixed resistance to carbapenem antibiotics (Caspar and Maurin, 2017) which is thought to be conferred by the Class A carbapenemase FPH-1 in Francisella philomiragia and potentially the F. tularensis blaA2 gene (Bina et al., 2006). The European holarctic strains are all resistant to imipenem, and several strains are resistant to meropenem, with Japanese strains showing mixed sensitivity/resistance to imipenem and carbapenem (Caspar and Maurin, 2017).

Carbapenem-resistance in E. coli and other Gram-negative bacteria is often mediated by the acquisition of mobile genetic elements that confer this phenotype. Francisella appears to have some inherent carbapenem resistance via the betalactamase genes, which are chromosomally located not plasmid-mediated. F. philomiragia is reported to have a chromosomally encoded Class A carbapenemase gene, FPH1 (Toth et al., 2012). Class A carbapenemases are reported to confer reduced susceptibility to imipenem to bacteria expressing them (Naas et al., 2016). FPH-1 appears to provide a broad spectrum of resistance, including expanded-spectrum cephalosporins, aztreonam, and carbapenems. The Francisella blaA2 chromosomal gene FTT0611c which encodes FTU1 has been reported to act as a very weak carbapenemase (Antunes et al., 2012). In published experiments, FTU-1 expression elevates the MIC of only imipenem twofold (Antunes et al., 2012), while FPH-1 elevates the MICs $(8 x-64 x)$ of imipenem, meropenem, ertapenem, and doripenem (Toth et al., 2012). Based on their somewhat unusual sequences and their activity profiles, these Francisella beta-lactamase genes (FPH-1, FTU-1, and FTU-2) have been placed on a new and distinct branch of the class A beta-lactamase tree (Naas et al., 2016).

\section{Aminoglycoside Resistance}

While the reported in vitro MICs for many antibiotic classes (Maurin et al., 2000) are low against Francisella, clinical tularemia treatment involves only three antibiotic classes: the fluoroquinolones, tetracyclines, and aminoglycosides (Boisset et al., 2014; Caspar and Maurin, 2017). However, treatment failures with these classes of antibiotics have been reported for up to $25 \%$ of tularemia cases (Perez-Castrillon et al., 2001; Boisset et al., 2014; Caspar and Maurin, 2017). Aminoglycoside antibiotics include gentamicin, streptomycin, amikacin, and tobramycin. Of these, only streptomycin has demonstrated a $100 \%$ cure rate for tularemia, but is not commonly used due to the intramuscular administration route and potential toxicity (Foshay and Pasternack, 1946; Enderlin et al., 1994). More recently, the fluoroquinolones such as ciprofloxacin and levofloxacin (Levaquin) have been shown to be effective in vitro and in vivo against this infection (Klimpel et al., 2008; Nelson et al., 2010; Peterson et al., 2010; Propst et al., 2016a; Caspar and Maurin, 2017). Assessment of the susceptibility of intracellular bacteria to these antibiotics may more closely mimic the in vivo response to these antibiotics (Maurin et al., 2000). Despite treatment failures, naturally occurring Francisella strains with aminoglycoside resistance have not been reported. Multiple transposon mutants in F. novicida have been identified as being hypersensitive to both gentamicin and spectromycin (see Figure 3 in Enstrom et al., 2012), including mutatations in $h s l V U, y c c A$, and $\operatorname{soh} B$, all genes associated with proteolysis.

Spectinomycin is an antibiotic of the aminocyclitol class of antibiotics which inhibits protein synthesis by reversibly binding the $16 \mathrm{~S}$ RNA of the $30 \mathrm{~S}$ ribosomal subunit, and has a bacteriostatic mode of action (Chopra, 2010). It has been used to treat gonorrhea infections. New derivatives of spectinomycin (novel $N$-benzyl aminomethyl spectinomycins) were found to be effective in vivo in a murine model against $F$. tularensis (Scarff et al., 2019). A low incidence of spontaneous AMR to spectinomycin has been reported in Francisella (Kormilitsyna and Marakusha, 1983), but in the laboratory, resistant mutants were readily obtained in vitro and under selection pressure (Bhatnagar et al., 1994). Thus, this antibiotic demonstrates potential for use, especially against a fluorquinolone antibioticresistant strain, if one were to be identified clinically.

Aminoglycoside resistance in Francisella is an interesting topic. While there are known aminoglycoside-modifying proteins in other genera, none are known in Francisella. The known mechanisms of resistance to aminoglycosides in Francisella are efflux-pump-based (Table 4).

The chromosome of Francisella bacteria encodes several multidrug efflux pumps (Table 4). AcrAB complex operates in conjunction with an outer membrane porin (such as TolC) to pump various substrates out of the cell as a multidrug efflux pump (Bina et al., 2008) (Figure 1). AcrA (FTT_0106c) is a cytoplasmic-membrane fusion protein, while AcrB (FTT_0105c) is an efflux pump protein. AcrAB may be involved in beta-lactam and cephalosporin resistance (Bina et al., 2008; Caspar and Maurin, 2017); for example, AcrAB was found to be important for azithromycin resistance (Ahmad et al., 2010). AcrAB is also responsible for some detergent resistance in Francisella. Interestingly, when combined with non-ionic detergents, cephalosporins appear to be more effective against Francisella, whereas the same is not true of ampicillin, suggesting differential mechanisms of resistance (Pavlovich and Tsimbalistova, 2019), 
TABLE 4 | The annotated efflux pumps in Francisella species and subspecies.

\begin{tabular}{|c|c|c|c|}
\hline & $\begin{array}{l}\text { Francisella tularensis subsp. } \\
\text { tularensis Schu S4 }\end{array}$ & $\begin{array}{l}\text { Francisella tularensis subsp. } \\
\text { holarctica LVS }\end{array}$ & $\begin{array}{l}\text { Francisella tularensis subsp. } \\
\text { novicida U112 }\end{array}$ \\
\hline & $\begin{array}{l}\text { Locus (KEGG orthology, Uniprot) } \\
\text { name [E.C. number], other } \\
\text { information }\end{array}$ & $\begin{array}{l}\text { Locus (KEGG orthology, Uniprot) } \\
\text { name [E.C. number], other } \\
\text { information }\end{array}$ & $\begin{array}{l}\text { Locus (KEGG orthology, Uniprot) } \\
\text { name [E.C. number], other } \\
\text { information }\end{array}$ \\
\hline \multicolumn{4}{|l|}{ Outer membrane efflux proteins } \\
\hline $\begin{array}{l}\text { TolC (OMP), outer membrane efflux } \\
\text { protein, tolC precursor }\end{array}$ & FTI_1724c (K12340) & FTL_1865 (K12340) & FTN_1703 (K12340, A0Q8J5) \\
\hline \multicolumn{4}{|l|}{ AcrAB system } \\
\hline $\begin{array}{l}\text { AcrA, efflux transporter, RND family, } \\
\text { MFP subunit. MexH family. (Also } \\
\text { annotated as a Co/Zn/Cd efflux } \\
\text { system membrane fusion protein in } \\
\text { some strains) }\end{array}$ & FT__0106c (K03585) & FTL_1671 (K03585) & $\begin{array}{l}\text { FTN_1609 (K03585, A0Q8A4), RND } \\
\text { family efflux transporter, MFP subunit. } \\
\text { MexAB-OprM [MD:M00718] }\end{array}$ \\
\hline AcrB (RND) & $\begin{array}{l}\text { FIT_0105c transporter } \\
\text { AcrB/AcrD/AcrF family }\end{array}$ & FTL_1672 (Bina et al., 2008) & $\begin{array}{l}\text { FTN_1610 (K18138, A0Q8A5) } \\
\text { AcrB/AcrD/AcrF family }\end{array}$ \\
\hline FtIC & FTI_1095c & FTL_1107 & FTN_0779 \\
\hline \multicolumn{4}{|c|}{ Emr MFS-type multidrug efflux pump (EMR locus) (Alqahtani et al., 2018) } \\
\hline SilC & FTI_1258 & FTL_0686 (Alqahtani et al., 2018) & FTN_1277 \\
\hline $\begin{array}{l}\text { EmrA1, outer membrane efflux } \\
\text { protein, }\end{array}$ & FT__1257 (K03543) & $\begin{array}{l}\text { FTL_0687 (K03543) (Alqahtani et al., } \\
\text { 2018) }\end{array}$ & FTN_1276 (K03543) \\
\hline $\begin{array}{l}\text { EmrB, membrane fusion protein, } \\
\text { multidrug efflux system membrane } \\
\text { fusion protein; membrane fusion } \\
\text { component of tripartite multidrug } \\
\text { resistance system }\end{array}$ & FT__1256 (K03446) & $\begin{array}{l}\text { FTL_0688 (K03446) (Alqahtani et al., } \\
\text { 2018) }\end{array}$ & FTN_1275 (K03446) \\
\hline
\end{tabular}

\section{Other efflux systems}

\begin{tabular}{lll}
\hline $\begin{array}{l}\text { Efflux transporter, RND family, MFP } \\
\text { subunit. }\end{array}$ & $\begin{array}{l}\text { FTT_0747c, hypothetical protein (261 } \\
\text { aa), HlyD_D23 domain }\end{array}$ & FTL_1366 (partial, 105 aa) \\
$\begin{array}{l}\text { ErmE multidrug resistance antiporter } \\
\text { of cations and cationic drugs, small } \\
\text { multidrug resistance family proteins }\end{array}$ & \\
$\begin{array}{l}\text { ArsB (arsenite-antimonite efflux } \\
\text { family protein) }\end{array}$ & FTT_0853 & FTN_0718 (Uniprot A0Q5U5), (285 \\
arsR family transcriptional regulator & FTT_0868c & FTN_0799 \\
K03892, & \\
$\begin{array}{l}\text { arsenate/arsenite/antimonite- } \\
\text { responsive transcriptional repressor }\end{array}$ & & FTL_0370 \\
(Xu et al., 1996) & & \\
\end{tabular}

while simultaneously suggesting a potential synergistic mechanism based around the overloading of AcrAB.

In LVS, the outer membrane porin TolC (FTL_1865) (Table 4) was shown to be involved with resistance to gentamicin (Gil et al., 2006). Gentamicin is a common drug for treating patients with tularemia, which targets the 30 s ribosome and leads to inhibition of protein synthesis (Loughman et al., 2016). FtlC (FTL_1107), a TolC-like protein, is partially responsible for the AMR of Francisella against kanamycin and streptomycin FtlC (FTL_1107) (Gil et al., 2006). A third TolC-like protein encoding gene called SilC (FTL_0686), adjoining EmrA1/B a cytoplasmic membrane fusion protein gene (FTL_0687)/efflux pump pair (FTL_0688), is also found in many Francisella strains, including Schu S4 (Table 4) (Alqahtani et al., 2018). EmrB in E. coli is a known multiple drug resistance efflux pump (Lomovskaya and Lewis, 1992), along with EmrA1. It appears that EmrA1 is involved with resistance to streptomycin and neomycin but not gentamicin (Ma et al., 2014), as well as SDS (Enstrom et al., 2012) in Francisella. The relationship and interchangeability of the various TolC orthologs in Francisella are more thoroughly discussed in Kopping et al. (2019). The various pumps/membrane proteins/fusion proteins in Francisella are illustrated in Figure 1.

Research Question: What is the link between AcrAB, non-ionic detergents, and beta-lactam resistance in Francisella? 


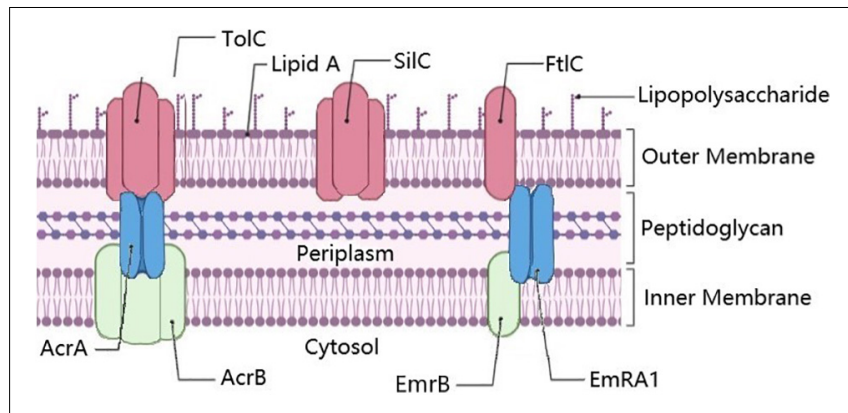

FIGURE 1 | Annotated efflux pump genes in Francisella. The membrane fusion proteins AcrA and EmrA1 proteins are shown in blue, the plasma membrane fusion proteins AcrB and EmrB in Green, and outer membrane proteins TolC, SilC, and FtIC in pink. SilC may also pair with EmrA1 and EmrB, especially as they are co-localized in the chromosome. Known trimers illustrated as such. Figure created using BioRender (https://biorender.com/).

Interestingly, gentamicin resistance in Francisella can be modulated by temperature. This was demonstrated via gentamicin conjugated to fluorescent dye entering the cell at different rates, with diminished antibiotic uptake at $26^{\circ} \mathrm{C}$ than $37^{\circ} \mathrm{C}$, perhaps suggesting that Francisella in environmental conditions as opposed to host conditions may acquire phenotypic resistance to compounds produced by other soil microbes, such as gentamicin (Loughman et al., 2016). The mechanism of this interesting phenotypic resistance mechanism has yet to be demonstrated, and is perhaps linked to the as-yet-unknown PMF-powered mechanism of gentamicin uptake into Francisella.

\section{Tetracycline Resistance}

Tetracycline is bacteriostatic for Francisella, and treatment of tularemia with this antibiotic can lead to relapses if treatment is not given for at least 14 days (Enderlin et al., 1994; Maurin et al., 2000; Perez-Castrillon et al., 2001). Most Francisella strains are susceptible to tetracycline in vitro with MIC ranging from 2.0 to $0.094 \mu \mathrm{g} / \mathrm{mL}$ (Baker et al., 1985; Ikaheimo et al., 2000). However, the clinical response of tularemia patients to the bacteriostatic antibiotic tetracycline appears to be subject to relapses and treatment failure (Baker et al., 1985; Maurin et al., 2000). Research on potential tetracycline resistance in Francisella is scant. A few studies have suggested that efflux pumps might be a potential mechanism of developing tetracycline resistance. Both TolC (Gil et al., 2006) and EmrA1 (Ma et al., 2014) proteins were also indicated in Francisella's resistance to tetracycline in vitro (Table 4). Tetracycline resistance has been engineered via plasmid into Francisella (Pavlov et al., 1996; LoVullo et al., 2012; McWhinnie and Nano, 2014), demonstrating that this resistance is certainly possible by introducing a tetracycline pump as a selection marker. In addition, a plasmid was constructed for Francisella to enable tetracycline-inducible protein-expression system in this organism (Sheshko et al., 2021).

Interestingly, bioinformatics analysis revealed the presence of tetracycline resistance protein (Tet) in most strains of Francisella (Biswas et al., 2008). Shown in Table 5 are the identified or annotated Tet protein genes in Francisella. This protein is an MFS-type multidrug transporter, which suggests that Francisella could pump out this compound as a mechanism of resistance.

Doxycycline, also a member of the tetracycline class, is among the drugs recommended by the CDC for treatment of tularemia (Dennis et al., 2001) and is bacteriostatic. Generally, doxycycline is very effective against tularemia with an MIC reported between 0.064 and $4 \mathrm{mg} / \mathrm{L}$ and no doxycycline-resistant strains have been reported in nature (Caspar and Maurin, 2017). Interestingly, ciprofloxacin-resistant Francisella strains have an approximately 2-10-fold increase in the MIC for doxycycline in two studies, suggesting that some cross-resistance may be happening (Biot et al., 2020; Sutera et al., 2014b). There is overall very little research on the mechanism and frequency of doxycycline resistance in Francisella.

Research Question: What is the role of tetracycline resistance protein (Tet) in tetracycline sensitivity or resistance in Francisella?

\section{Polymyxin Resistance}

Polymyxins are cationic cyclic peptide antibiotics that are drugs of last resort for many multidrug resistant infections. They are also often invoked as models for the mechanism of action of innate immune system cationic antimicrobial peptides. Polymyxin resistance is usually due to modification of the LPS of Gram-negative bacteria (Schaenzer and Wright, 2020), in particular the Lipid A (Li et al., 2012). Francisella is also known to be highly resistant to polymyxins (Llewellyn et al., 2012; Stephens et al., 2016), and it is used as part of Francisella selective media to counter select against faster growing organisms. In fact, $100 \mu \mathrm{g} / \mathrm{mL}$ polymyxin $\mathrm{B}$ is added to selective media for the isolation of Francisella from organ homogenates (Petersen et al., 2004a,b, 2009). Francisella LPS varies by strain, but its LPS is unusual as compared to that of other Gram-negative bacteria as it does not activate Toll-like receptor 4 , a host protein

TABLE 5 | Identification of putative tetracycline resistance genes (Tet) in most strains of Francisella (selected data from Uniprot.org).

\begin{tabular}{|c|c|c|c|c|c|}
\hline Gene locus number & Organism & UniProt entry & NCBI-ProteinID & Protein names & Protein length \\
\hline FTT_0444 (tet) & $\begin{array}{l}\text { Francisella tularensis subsp. } \\
\text { tularensis (strain SCHU } \\
\text { S4/Schu 4) }\end{array}$ & Q5NHK9 & YP_169483 & $\begin{array}{l}\text { Multidrug transporter MFS_1 } \\
\text { (tetracycline resistance protein) }\end{array}$ & 412 \\
\hline FTL_1622 & $\begin{array}{l}\text { Francisella tularensis subsp. } \\
\text { holarctica LVS }\end{array}$ & A0A0B3VY25 & CAJ80061 & $\begin{array}{l}\text { MFS transporter (Sugar (And } \\
\text { other) transporter family protein) }\end{array}$ & 408 \\
\hline FTN_0535 & $\begin{array}{l}\text { Francisella tularensis subsp. } \\
\text { novicida strain U112 }\end{array}$ & A0Q5B5 & ABK89430 & $\begin{array}{l}\text { Drug:H+ antiporter-1 (DHA1) } \\
\text { family protein }\end{array}$ & 408 \\
\hline
\end{tabular}


largely responsible for inflammation in response to bacterial LPS (endotoxin) (Gunn and Ernst, 2007). Specifically, the Francisella LPS is tetra-acylated and has C16-C18 length tails, which is quite different than E. coli LPS (Vinogradov et al., 2002; Li et al., 2012; Okan and Kasper, 2013).

The main mechanism of resistance is through polymyxin binding of LPS, and most of the "Polymyxin Resistance" genes annotated in Francisella (Table 6) are involved with either the assembly or creation of LPS components (Sampson et al., 2014). The lipid A component in Francisella is different from that of E. coli in that the lipid A of Francisella has the hydroxyl group of the 2'-linked fatty acyl chain of lipid A esterified with C16:0. In contrast, E. coli has two phosphates at the 1' and 4'. Francisella lipid A also has an unusual $\alpha$-linked galactosamine addition at the 1-position and is lacking the traditional phosphate at the 4'-position of the carbon ring (Okan and Kasper, 2013). There are a handful of proteins known to enable these LPS modifications. The role of some of these genes including $l p x D 1$ and $l p x D 2$ ( $\mathrm{Li}$ et al., 2012) as well as $l p x F$ (Wang et al., 2007) in polymyxin resistance was confirmed experimentally in Francisella. LpxD1 and LpxD2 are responsible for acylating LPS (Yun et al., 2017), whereas LpxF is responsible for dephosphorylation of 4' phosphates in Francisella LPS (Wang et al., 2006). A deletion mutant in F. novicida LpxD2 conferred significant increase in polymyxin $B$ resistance, while a deletion mutant in $l_{p x D 1}$ caused a sensitivity to polymyxin B (Li et al., 2012). Indeed, the lpxD1-Null Mutant is both avirulent and protective as an attenuated vaccine strain ( $\mathrm{Li}$ et al., 2012). LpxA, a protein which catalyzes lipid A synthesis (Joo and Chung, 2016), from F. novicida was shown to be active in the production of Lipid A when expressed in E. coli (Joo and Chung, 2016).

Polymyxin resistance also involves bacterial lipoprotein (BLP) regulated by the CRISPR-Cas protein Cas9 in $F$. novicida (Sampson et al., 2013). Repression of BLP expression leads to enhanced polymyxin B resistance, suggesting that this protein may play a role in the action of polymyxin as an antibiotic in Francisella.

Another pair of genes, including arnT (undecaprenyl phosphate-alpha-L-Ara4N transferase) and arnC (glycosyl transferase family 2, FTU_0505), are also annotated as "Polymyxin resistance genes" in some Francisella strains and have homologs in other strains (Table 6) (Li et al., 2012). ArnC and ArnT add sugars to LPS following the dephosphorylation event performed by LpxD1 and LpxD2 (Okan and Kasper, 2013). The nature of these additions is strain dependent and the role, if any, of these genes in Francisella antibiotic resistance has not been determined.

In some cases, Francisella's resistance to polymyxin can also be affected by other signaling pathways, including the twocomponent system which can alter the expression of multiple genes, including those that affect polymyxin resistance. We found that the Francisella two-component system response regulator BfpR (FTN_1452/FTT_1543) regulates the expression of a gene encoding glycosyltransferase potentially similar to arnC (FTN_0545, FlmF2, or yfdH) (Richards et al., 2008; Wang et al., 2009), which was found to be significantly deceased (0.45fold) in the $b f p R$ mutant strain relative to wild-type $F$. novicida (Dean et al., 2020).

\section{Cationic Antimicrobial Peptide Resistance}

Gram-negative bacteria have multiple known mechanisms by which they can resist the action of the cationic antimicrobial peptides (Band and Weiss, 2015), which are being investigated as antibacterial agents against Francisella (Han et al., 2008; Amer et al., 2010; Flick-Smith et al., 2013; Chung et al., 2015; Findlay et al., 2016; Kaushal et al., 2016; Propst et al., 2016a; Dean et al., 2020). Polymyxin B and colistin are both cationic polypeptide antibiotics. KEGG has annotated the following genes as playing a role in cationic antimicrobial peptide resistance in Francisella (KEGG, 2020): The multidrug resistance efflux pump of the MexAB-OprM class tolC, $\operatorname{acr} A, \operatorname{acrB}$ (FTT_1742c [FTN_1703], FTT_1016c [FTN_1609], and FTT_0105c [FTN_1610], respectively) and $l p x A$, an LPS biosynthesis gene (FTT_1569c [FTN1478]). However, this annotation as being important in cationic antimicrobial peptide resistance has not been experimentally confirmed for any of these. tolC mutants had the same polymyxin sensitivity as wild-type F. tularensis SchuS4 (Kopping et al., 2019). Experiments examining the importance of AcrA/B/TolC in F. tularensis LVS have also not demonstrated a role for these genes in polymyxin resistance (Gil et al., 2006; Kopping et al., 2019). LpxA, the LPS biosynthesis gene FTT_1569c [FTN1478], was annotated by KEGG as playing a role in cationic antimicrobial peptide resistance and interacting with AcrA/B/TolC. Resistance to the cationic polypeptide polymyxin in Francisella is thought to be mediated mainly by its LPS as discussed above.

Recently, we have demonstrated that mutants in the twocomponent system BfpR in Francisella lead to a phenotype of antimicrobial peptide resistance in $F$. novicida for two antimicrobial peptides, the human cathelicidin peptide LL-37 and a sheep antimicrobial peptide SMAP-29 (Dean et al., 2020). This mechanism may be through regulation of biofilm formation, or some yet undetermined mechanism.

Research Question: What are the genes responsible for resistance to cationic antimicrobial peptides in Francisella? Are there any other genes in addition to LPS synthesis genes that play a role?

\section{Macrolide Resistance (Erythromycin) and Sensitivity (Azithromycin)}

Macrolides are polyketide antibiotics that are typically bacteriostatic and work by inhibiting protein synthesis through binding to the $50 \mathrm{~S}$ ribosome. Macrolides include erythromycin and azithromycin.

Erythromycin has limited efficacy against many Gramnegative bacteria due to its hydrophobic nature and lack of permeability through the Gram-negative outer membrane 
TABLE 6 | Putative polymyxin resistance genes in Francisella (selected data from Uniprot.org and Kegg.jp).

\begin{tabular}{|c|c|c|c|c|c|c|}
\hline Locus (gene) names & Organism & UniProt entry & Phenotype & Protein names & Length & References \\
\hline \multicolumn{7}{|l|}{ LpxF type } \\
\hline FTN_0295 (JpxF) & $\begin{array}{l}\text { Francisella tularensis subsp. novicida } \\
\text { (strain U112) }\end{array}$ & AOQ4N6 & Polymyxin Sensitivity & Lipid A 4'-phosphatase & 222 & Wang et al., 2007 \\
\hline FTT_1634c & $\begin{array}{l}\text { Francisella tularensis subsp. tularensis } \\
\text { (strain SCHU S4) }\end{array}$ & Q5NEJ5 & & Hypothetical Protein & 222 & \\
\hline FTL_1704 & $\begin{array}{l}\text { Francisella tularensis subsp. holarctica } \\
\text { LVS }\end{array}$ & Q2A1R7 & & Hypothetical Membrane Protein & 222 & \\
\hline \multicolumn{7}{|l|}{ ArnT type } \\
\hline FN3523_1260 & Francisella hispaniensis & AEE26563 & & $\begin{array}{l}\text { Polymyxin resistance protein ArnT, } \\
\text { undecaprenyl } \\
\text { phosphate-alpha-L-Ara4N transferase } \\
\text { Melittin resistance protein PqaB }\end{array}$ & 587 & \\
\hline FTT_0455c & $\begin{array}{l}\text { Francisella tularensis subsp. tularensis } \\
\text { SCHU S4 }\end{array}$ & Q5NHJ9 (YP_169493) & & $\begin{array}{l}\text { Dolichyl-phosphate-mannose-protein } \\
\text { mannosyltransferase family protein }\end{array}$ & 587 & Phillips et al., 2004 \\
\hline FTN_0546 & $\begin{array}{l}\text { Francisella tularensis subsp. novicida } \\
\text { (strain U112) }\end{array}$ & A0Q5C6 & & $\begin{array}{l}\text { Dolichyl-phosphate-mannose-protein } \\
\text { mannosyltransferase family protein }\end{array}$ & 587 & \\
\hline FTL_1609 & $\begin{array}{l}\text { Francisella tularensis subsp. holarctica } \\
\text { LVS }\end{array}$ & CAJ80048 & & $\begin{array}{l}\text { Dolichyl-phosphate-mannose-protein } \\
\text { mannosyltransferase family protein }\end{array}$ & 586 & \\
\hline \multicolumn{7}{|l|}{ ArnC Type } \\
\hline FN3523_1261 & Francisella hispaniensis & F4BGHO & & $\begin{array}{l}\text { Polymyxin resistance protein ArnC, } \\
\text { glycosyl transferase }\end{array}$ & 317 & \\
\hline FTT_0454 (yfdH) & $\begin{array}{l}\text { Francisella tularensis subsp. tularensis } \\
\text { (strain SCHU S4) }\end{array}$ & Q5NHKO & & $\begin{array}{l}\text { Glycosyl transferase, group } 2 \text { family } \\
\text { protein }\end{array}$ & 318 & \\
\hline FTN_0545 & $\begin{array}{l}\text { Francisella tularensis subsp. novicida } \\
\text { (strain U112) }\end{array}$ & A0Q5C5 & & Glycosyl transferase, group 2 & 318 & \\
\hline FTL_1611 & $\begin{array}{l}\text { Francisella tularensis subsp. holarctica } \\
\text { LVS }\end{array}$ & A0A0B6E7W3 (CAJ80050) & & $\begin{array}{l}\text { Glycosyl transferase, group } 2 \text { family } \\
\text { protein }\end{array}$ & 317 & \\
\hline
\end{tabular}

At least three categories of Francisella genes have "polymyxin resistance" terms associated with them: IpxF, arnC, and arnT genes. 
(Saha et al., 2008). Some strains of Francisella are intrinsically resistant to erythromycin; no reports of acquired resistance have been found. Interestingly, different sub-strains of Francisella have different susceptibility to erythromycin. The Eurasian strains (biovar II) of Francisella are often erythromycin resistant (Urich and Petersen, 2008; Karlsson et al., 2016). In the holarctica strains (F. tularensis subsp. holarctica), biovar I was found to be erythromycin sensitive, whereas biovar II B.12 strains including the live vaccine strain (LVS) were found to be erythromycinresistant (Kudelina and Olsufiev, 1980). A common mechanism of resistance to macrolides is the modification of the $23 \mathrm{~S}$ rRNA, the $r r l$ gene. F. tularensis LVS was found to have a point mutation in Domain V of the 23S rRNA, rendering it more resistant to erythromycin than F. novicida or F. tularensis Schu S4 (Biswas et al., 2008). This modification could explain the increased resistance to erythromycin in F. tularensis LVS. SNP analysis confirmed that this resistance was due to the presence of $\mathrm{A} \rightarrow \mathrm{C}$ SNP at position 2059 in the three copies of the $r r l$ gene. Introducing this mutation into erythromycin-sensitive Francisella strains rendered them resistant (Karlsson et al., 2016). Exposure in vitro of $F$. tularensis subsp. holarctica biovar I strains to increasing erythromycin concentrations can lead to resistance mutations in 23S RNA and other sites as well as upregulation of efflux pumps (Gestin et al., 2010). In the North American Type A Francisella strains, erythromycin MICs range from 0.5 to $2 \mu \mathrm{g} / \mathrm{mL}$, while F. tularensis holarctic strains have observed MICs of 4 to $>256 \mu \mathrm{g} / \mathrm{mL}$ (Marinov et al., 2009; Caspar and Maurin, 2017).

In addition, certain methylases can confer increased resistance by methylation of a specific adenine residue of the 23S rRNA. Methylases that have been identified as Francisella critical virulence factors might have this activity (Kraemer et al., 2009). Some methylases present in the genome of $F$. novicida are either absent or pseudogenes/non-functional genes in $F$. tularensis Schu S4 (such as FTT0010, FTT0770, FTT1430, FTT1719, and FTT1735c), potentially contributing to the different sensitivities to erythromycin between the strains (Larsson et al., 2005).

Research Question: What is the potential role of these methylases in acquired erythromycin resistance in Francisella? This has not yet been experimentally determined.

Azithromycin (Zithromax) is a very commonly prescribed macrolide antibiotic for the pediatric populations. Therefore, there is interest in its potential use for treating pediatric tularemia patients (CIDRAP, 2013). Azithromycin is currently approved as a pediatric macrolide in use in the United States and Europe. Azithromycin has the amazing pharmacokinetic property of concentrating inside macrophages up to $1000 \mathrm{x}$ the serum concentration. We found that azithromycin was more effective against the Gram-negative Francisella bacteria than was expected (Ahmad et al., 2010). Despite reports that European clinical strains of Type B F. tularensis holarctica and Japanese palaearctica biovar strains are resistant to azithromycin in vitro (MIC > $256 \mu \mathrm{g} / \mathrm{mL}$ ) (Ikaheimo et al., 2000), we observed that commonly used laboratory strains were sensitive to this antibiotic. We have demonstrated that the Type A F. tularensis tularensis strains are sensitive to azithromycin in vitro (Ahmad et al., 2010). F. philomiragia (an environmental strain of Francisella) and F. novicida are also sensitive to this drug with similar MICs. The MIC for $F$. tularensis LVS (NR646) was $25 \mu \mathrm{g} / \mathrm{mL}$ azithromycin, confirming the finding that LVS and holarctic strains are relatively more resistant than other Francisella strains. Furthermore, due to the high concentrating effect in macrophages for azithromycin (approximately $\sim 1000 \mathrm{x}$ the serum concentration), the bacteria were effectively killed in the intracellular state by this antibiotic (Ahmad et al., 2010). As mentioned above, $\mathrm{Acr} A \mathrm{~B}$, the inner-membrane component of the TolC/AcrAB Type 1 secretion system, was found to be important for azithromycin resistance (Ahmad et al., 2010).

\section{Rifampin Resistance}

Rifampin, also known as Rifampicin, is a broad-spectrum antibiotic used to treat bacterial infections, mostly tuberculosis in humans. In veterinary medicine, rifampin is used to treat various Gram-positive infections including Staphylococcus, Streptococcus, and most strains of Bacteroides, Clostridium, Neisseria, and Listeria. Gram-negative organisms are not usually affected by rifampin at the typical doses administered. Rifampin works by inhibiting transcription, specifically by interfering with bacterial DNA-dependent RNA polymerase (Chen and Kaye, 2011; Alifano et al., 2015). Rifampin has a very interesting pharmacokinetic profile, which includes accumulating inside cells and thus can exert antibacterial effects against intracellular bacteria (Chen and Kaye, 2011).

Resistance to rifampin in E. coli is due to mutations in the $r p o B$ gene, which affects the activity of RNA polymerase (Chen and Kaye, 2011). This mutation has not been seen clinically for Francisella. Experimentally, rifampin resistance has been generated by growth under the increasing concentration of rifampin. When these mutants were tested for their virulence in vivo, it was found that these mutants had decreased virulence compared to the wild-type Francisella (Bhatnagar et al., 1994). There is one transposon-insertion mutant available in $r p o B$ in F. novicida (Gallagher et al., 2007), suggesting that this gene is not an absolutely essential gene.

An emerging use for rifampin is as an adjunct therapy or combination therapy with other antibiotics or antimicrobials in other organisms (Maslow and Portal-Celhay, 2015). Rifampin inhibition of Francisella growth is bacteriostatic (Baker et al., 1985), but it could be used in combination with other antibiotics or possibly in combination with antimicrobial peptides, as we recently demonstrated for Mycobacteria (Gupta et al., 2015). The synergy between colistin and rifampin has been observed in several multidrug-resistant bacteria, further supporting this approach (Chen and Kaye, 2011).

\section{Fosmidomycin Resistance and the DXR/MEP Pathway}

Bacteria, algae, and plants all produce isoprenoids through the methylerythritol phosphate (MEP) pathway. As the MEP 
pathway is only present in prokaryotes and some lower eukaryotes, but not in mammalian cells, the pathway is attractive for antimicrobial drug development (Jawaid et al., 2009; Mackie et al., 2012; McKenney et al., 2012). Genes in the MEP pathway have been identified in many bacterial biothreat agents, including Francisella. The importance of the MEP pathway to Francisella is illustrated by the lethality of mutations in the MEP pathway genes (Jawaid et al., 2009; McKenney et al., 2012).

The first committed step of the MEP pathway is catalyzed by the enzyme 1-deoxy-D-xylulose 5-phosphate reductoisomerase (DXR/MEP synthase) (Jawaid et al., 2009). We have previously established that fosmidomycin and the prodrug FR900098 inhibit purified F. tularensis LVS MEP synthase enzyme (DXR IC50 = $230 \mathrm{nM}$ ) (Jawaid et al., 2009). We subsequently demonstrated that fosmidomycin is somewhat effective against the bacteria with an MIC of $136 \mu \mathrm{M}$, and strongly suppressed the growth of intracellular Francisella suggesting that fosmidomycin and the prodrug may be active in vitro against this organism (McKenney et al., 2012). We cultured F. novicida with FR900098 antibiotic disks and selected the resistant mutants that appeared for sequencing. Resistance to fosmidomycin was not directly developed in the DXR gene, as one might predict, but rather turned out to be an indirect target, through mutation of a transporter, GlpT (Mackie et al., 2012). This transporter is responsible for the ability of the drug to enter the bacteria, and mutations in the transporter render the antibiotic ineffective as demonstrated by colonies appearing in the inhibition zone. This transporter mutant turned out to be a very powerful screen for lipophilic versions of fosmidomycin-related compounds that can act on intracellular Francisella and DXR in a GlpT-independent manner (Figure 2).

\section{Emerging Fluoroquinolone Resistance in Francisella}

Fluoroquinolones are broad-spectrum antibiotics which inactivate bacterial topoisomerases and gyrases, which are responsible for the supercoiling of bacterial DNA and, therefore, its replication. Many proposed mechanisms of resistance to fluoroquinolones in Francisella revolve around the mutation of the antibiotic target. As shown in serial passage experiments in Francisella, mutations in type II gyrases GyrA (FTT_1575c) and GyrB (FTT_0510), as well as mutations in type IV topoisomerases ParE (FTT_0163c) or ParC (FTT_0396), confer enhanced resistance to fluoroquinolones (Sutera et al., 2014b) (Figure 2). A similar study in Francisella LVS also identified GyrA as the main target of induced ciprofloxacin resistance (Jaing et al., 2016). The specific regions altered in Gyr A that give Francisella enhanced resistance are residues 83 and 87 , which are involved in the catalytic domain, 43, 523, and 524 which are involved with DNA binding (Figure 2A). Those altered in GyrB are catalytic residues 464-466, DNA binding residues 486, 487 , and 747 , as well as mutation in residues 570 and 86 , which have unknown roles in protein functionality (Sutera et al., 2014b; Caspar et al., 2017) (Figure 2B).

The mutations on ParEC followed a similar pattern with the catalytic residue 82 of ParC and the DNA binding residue of ParE

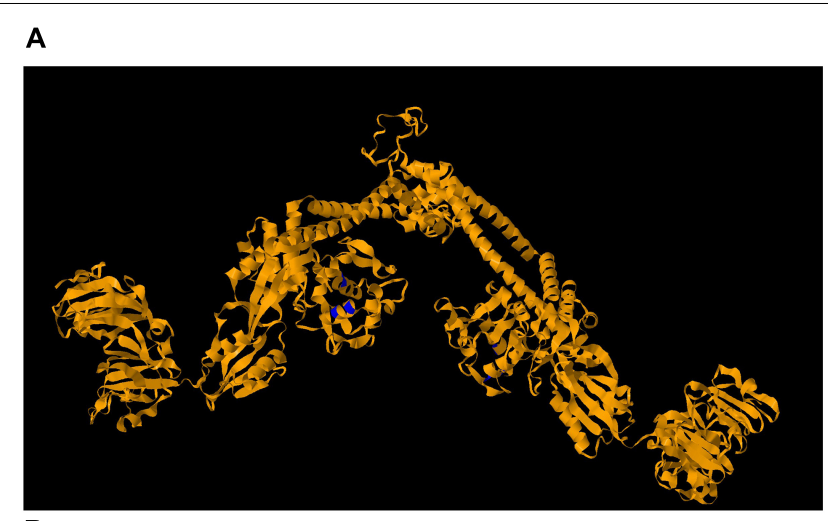

B

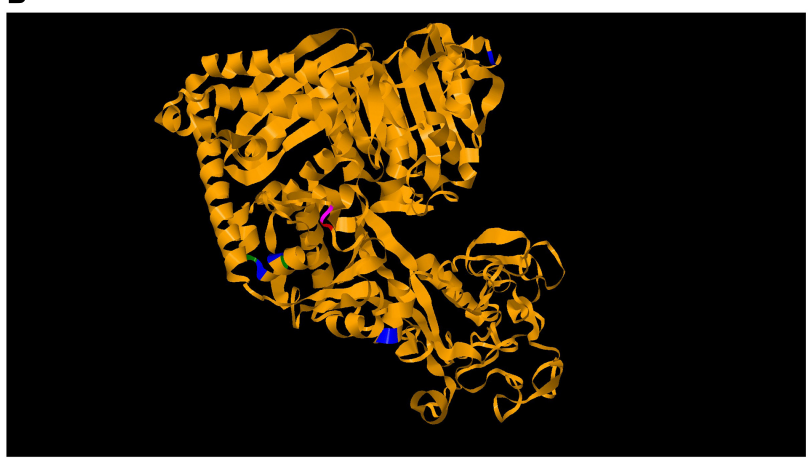

C

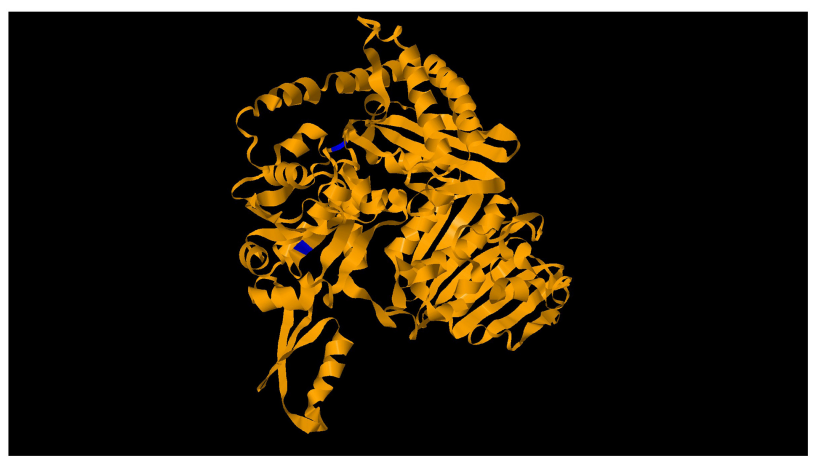

FIGURE 2 | DNA gyrase in Francisella, showing critical residues. The Francisella tularensis tularensis ScuS4 GyrA (A), GyrB (B), and ParE (C) amino acid sequences were used in conjugation with SwissModel (Schwede et al., 2003) to generate three-dimensional protein models. The model of each with the highest global model quality estimation score is presented here in orange. On each model, mutations leading to enhanced resistance were mapped. Blue indicates a substitution of residue, red a deletion, green an insertion after the indicated residue, and magenta either a deletion or a substitution at that residue. Protein models were built in SWISS-MODEL and illustrated in Geneious (Schwede et al., 2003; Kearse et al., 2012).

472 (Sutera et al., 2014b) (Figure 2C). However, these mutations alone could not explain differential MIC results, suggesting that there may be secondary mechanisms which contribute to fluoroquinolone resistance. This disparity is further highlighted by the fact that tularemia patients who failed to respond to fluoroquinolone treatment did not contain Francisella with gyrase and topoisomerase mutations (Sutera et al., 2017). This suggests that alternative mechanisms of resistance, such as efflux 
pumps, which may also contribute to fluoroquinolone resistance, may be important as well (Sutera et al., 2014b). Efflux pump components TolC (Gil et al., 2006), EmrA1 (Ma et al., 2014), and SilC (Alqahtani et al., 2018) have been associated with resistance to the quinolone nalidixic acid, supporting this hypothesis.

It was found that deletion of FupA/B gene (FTT_0918), which encodes an iron-binding membrane protein, also contributed to fluoroquinolone resistance. While the exact mechanism is unclear, the authors suggest that deletion of FupA/B destabilizes the cell membrane leading to a larger production of OMVs, which may shield the bacteria from the antibiotic in some way (Siebert et al., 2019).

Transposon insertions into $\operatorname{rec} A B C D$ and $\operatorname{ruv} A B C$ genes increased the sensitivity to quinolones in $F$. novicida, and the replication helicase $(r e p)$ and exonuclease I $(s b c B)$ may also play a role (Enstrom et al., 2012).

\section{EFFLUX PUMPS IN Francisella}

Francisella species contain genes for very few efflux pumps (Table 4 and Figure 1). Overall, there are three closely related pumps, classified as Type I secretion systems, including the TolC/AcrA/B efflux pump (Kopping et al., 2019), the TolC homolog FtlC (Gil et al., 2006), as well as SilC and the HylD/EmrA1 system (Ma et al., 2014; Alqahtani et al., 2018). The TolC/AcrA/AcrB complex is an important and well-characterized multidrug-resistant efflux pump in Francisella (Kopping et al., 2019). As described in the sections above, the TolC/AcrA/AcrB efflux pump is shown to play important roles in erythromycin, SDS (Kopping et al., 2019), and aminoglycoside resistance (Gil et al., 2006). SilC/EmrA1 was shown to be important in streptomycin and polymyxin resistance (Alqahtani et al., 2018), although not polymyxin resistance in SchuS4 (Kopping et al., 2019). Overall, Thanassi et al. have demonstrated that the TolC, FtlC, and SilC systems have overlapping and distinct patterns of resistance, suggesting overlapping and distinct efflux functions (Kopping et al., 2019). New methods such as highthroughput screening systems to test for compounds that inhibit Francisella efflux pumps may advance this area of research (Haynes et al., 2018). Thus, these systems appear to represent the full complement of multidrug efflux pump systems in the genus Francisella.

Additional efflux systems have been identified which are not classified as multidrug efflux systems and are summarized below. Studying the annotated genes in Francisella in various databases suggests that the following genes may also be part of efflux pump systems for various metabolites including arsenite. A new antibiotic has been identified from soil bacteria, the organiarsenical arsinothricin, which targets glutamine synthetase. This antibiotic has been shown to be effective against Gram-negative and Gram-positive bacteria, although Francisella was not tested (Nadar et al., 2019). Interestingly, resistance to this antibiotic is mediated by $\operatorname{arsN1}$, a gene in the bacterial arsenic resistance (ars) operons. While arsN1 was not identified in Francisella, multiple genes have been found in this organism that are related to arsenite resistance, especially $\operatorname{ars} R B$, where $\operatorname{ars} B$ is the arsenite-antimonite efflux family protein gene, and $\operatorname{ars} R$ is the arsenate/arsenite/antimonite-responsive transcriptional repressor gene. This pump system is responsible for the resistance to trivalent arsenite by its extrusion from bacterial cells and it contains the conserved 10 transmembrane domain structure with a conserved catalytic cysteine (Fu et al., 2009). The genes encoding this system have been well described in F. philomiragia, a related environmental strain (Siddaramappa et al., 2012). As one example, FTN_0382 is annotated as encoding a potential ArsB protein, while FTN_0395 is annotated as encoding a potential ArsR. Multiple winged helix-turn-helix transcriptional regulator proteins are identified as being related to ArsR in a search of NCBI/NLM database in F. novidida including FTN_0395, FTN_0801, FTN_0858, FTN_1022, FTN_1534, and FTN_1393. Two potential $a r s B$ genes are identified by this search, including FTN_0382 and FTN_0800. For example, an arsenic resistance locus has been putatively identified in F. novicida U112 by a computational approach, but not in all strains of Francisella. This locus includes emrE (FTN_0799), a gene which is annotated to be encoding a multidrug resistance antiporter of cations and cationic drugs; and $\operatorname{arsRB}$ (FTN_0800 and FTN_0801), two arsenite resistance genes, with $\operatorname{ars} B$ potentially being the arsenite efflux transporter and $\operatorname{ars} R$ potentially acting as the ArsR repressor (Siddaramappa et al., 2011). Of these, emrE (FTN_0799) and arsB (FTN_0800) were found to be required for F. novicida intracellular replication in U937 macrophages, while arsR (FTN_1393) was required for replication in Drosophila S2 cells (Asare and Abu Kwaik, 2010).

Research Question: In what ecosystem or lifecycle stage is F. novicida exposed to arsenite such that it potentially needs more than one arsenite resistance system? Does Francisella arsenite resistance cross-confer antibiotic resistance?

\section{PHENOTYPIC ANTIBIOTIC RESISTANCE IN Francisella DUE TO BIOFILM FORMATION}

One consequence of the formation of biofilm in bacteria is the phenotypic resistance to antibiotics. This is thought to be due to the protective nature of the extracellular polymeric substance of the biofilm, rather than any direct genetically encoded resistance mechanism. It has recently been found that many species within the genus Francisella can form biofilms to lesser (Type A/B) or greater (environmental strains) extents (Dean et al., 2009, 2015, 2020; Durham-Colleran et al., 2010; Margolis et al., 2010; Verhoeven et al., 2010; Zogaj et al., 2012; van Hoek, 2013; Soto et al., 2015; Champion et al., 2019). The nature of the biofilm matrix in Francisella remains under study, but its formation appears to be induced by stress (Dean et al., 2009) and is regulated at least in some Francisella species by ppGpp/relA (Dean et al., 2009, 2015; Zogaj et al., 2012) and a twocomponent system qseC/qseB (Durham-Colleran et al., 2010). Inducing dispersal of the biofilm via chitinase or BDSF increases the susceptibility of $F$. novicida to antibiotics and antimicrobial peptides (Chung et al., 2014; Dean et al., 2015, 2020). It was 
also shown that biofilm mode of growth reduced fluoroquinolone susceptibility of $F$. novicida, further supporting the hypothesis of the mechanism of biofilm-mediated phenotypic resistance (Siebert et al., 2019).

A recently study of spontaneous ciprofloxacin- and streptomycin-resistant strains of Francisella had the interesting finding that all the $F$. novicida ciprofloxacin-resistant mutants had significantly less biofilm formation than the F. novicida wildtype parent strain, while the F. novicida streptomycin-resistant strains did not show this effect (Biot et al., 2020). Molecular analysis of the off-target mutations in the ciprofloxacin resistant strains did not reveal any obvious regulators of biofilm production or degradation, thus this biofilm effect may be due to a general increase in stress for these mutants, indicated by their reduced fitness (Biot et al., 2020).

\section{NEW METHODS TO ASSESS ANTIMICROBIAL RESISTANCE OF Francisella AS AN INTRACELLULAR PATHOGEN}

Determining which antibiotic is most effective for treatment of a patient has always been challenging. Mimicking all in vivo conditions is impossible and persistent use of model animals impractical. Thus, methods such as MIC, minimum biocidal concentration (MBC), minimal concentration effective against biofilm (MCEB), and Kirby Bauer (specialized disk diffusion assay) have all been used to address these questions in vitro. While these methods are relatively inexpensive as well as amenable to high throughput, they lack in vivo characteristics to better confirm the efficacy of any antimicrobial against a particular pathogen.

\section{Activity in the Presence of Serum}

Francisella spends some portion of its lifecycle in a host, outside of a phagocytic cell, where it is subject to opsonization and uptake for destruction by immune cells. Thus, there is an opportunity for antimicrobial agents to encounter the bacterium in the blood or in the tissue, external to host cells. One way to better model in vivo response of the bacteria to any antibacterial agent may be to perform the MIC assays in the presence of serum, or even a serum bactericidal titer (SBT) assay (Zaghi et al., 2020). The presence of serum can model some aspects of antibiotic pharmacodynamics, and can directly affect the activity of antibacterial compounds such as peptides. An assay was developed using plasma from patient samples along with immunomagnetic separation to enhance detection (Aloni-Grinstein et al., 2017). Such approaches to improve detection of activity could improve the development of new potential therapeutics.

\section{Intracellular MIC Assay}

These problems of translating in vitro MIC results to in vivo clinical outcomes are magnified when regarding intracellular bacteria as the penetration, and local concentrations of antimicrobials within eukaryotic cells become extremely important. Researchers have developed intracellular MIC assays in which bacterial cells are phagocytosed by eukaryotic host cells, extracellular bacterial cells are killed by exogenous addition of antibiotic such as gentamicin, and then different populations of infected eukaryotic cells received different doses of a drug, similar to an MIC. After a time for incubation (18-24 h), bacterial cells are quantified either via eukaryotic cell lysis and cell plating (if possible) or a variety of other quantification methods based upon the bacterium in question. Such an assay was performed to demonstrate the synergistic activity of gallium to gentamicin against intracellular F. tularensis SchuS4 (Lindgren and Sjostedt, 2016).This method has been performed with Francisella and shows reasonable predictive power of patient outcome when compared to clinical data (Maurin et al., 2000). A more recent method developed by Sutera et al. involves a dye uptake assay to quickly and quantitatively measure the susceptibility of intracellular Francisella to extracellular antibiotics. If the bacteria are inhibited by the extracellular antibiotic, then they will have reduced intracellular replication and reduced host cell lysis compared to untreated controls. This method of staining for eukaryotic cell viability also included a focus on Francisella virulence factors as the bacterial cells need to not only enter the phagosome, escape to cytoplasm, and survive but lyze the eukaryotic cells for the eukaryotic cell measurement (via neutral red) to be reduced (Sutera et al., 2014a).

\section{Insect Models}

Insect models have recently been used to test the efficacy of antibiotics against Francisella. These in vivo models allow for the more complex conditions of a host to be incorporated into the assay. While ticks, biting flies, and mosquitoes are known insect vectors for this disease, recently published insect models for Francisella virulence include Drosophila melanogaster (Ahlund et al., 2010; Moule et al., 2010), the orange spotted cockroach (Eklund et al., 2017), and the wax worm larvae, Galleria mellonella (Aperis et al., 2007; Sprynski et al., 2014; Propst et al., 2016b; Thelaus et al., 2018; Djainal et al., 2020). The correlation between virulence factors in humans and virulence in the waxworm is not exact (Thelaus et al., 2018), thus this model needs to be used with care in interpretation of the results, especially with respect to host-directed virulence. However, if an infection is successfully established, the waxworm is a quick method of testing antibacterial activity of test compounds. The waxworm has been used as an insect model for antibiotic treatment studies for Francisella, demonstrating the activity of azithromycin and the prodrug of fosmidomycin, for example (Ahmad et al., 2010; McKenney et al., 2012), as well as ciprofloxacin, levofloxacin, or streptomycin (Aperis et al., 2007).

\section{Francisella qPCR-Based Antibiogram}

A recently developed method both addresses the intracellular antibiotic susceptibility problem and provides a much faster test method. Aloni-Grinstein et al. developed a method of Francisella antibiogram which uses qPCR and was able to confirm that gentamicin does not inhibit intracellular Francisella replication while other antibiotics such as doxycycline, chloramphenicol, 
and ciprofloxacin showed intracellular activity, consistent with results from both in vitro and clinical studies (Aloni-Grinstein et al., 2015). This rapid 3-h method was shown to provide a quantitative measure of minimal inhibitory extracellular concentration (MIEC), which is an important measure of the amount of extracellular antibiotic needed to eradicate intracellular Francisella bacteria. The authors were able to examine the results of the gentamicin studies and pose the question as to whether gentamicin is suitable for clinical use against tularemia given this lack of inhibition of intracellular replication (Aloni-Grinstein et al., 2015).

\section{Use of Transport Mutants to Identify Lipophilic Drug Candidates}

Finally, through the use of mutant bacteria from the transposon mutant library in F. novicida (Gallagher et al., 2007), intracellular screening assays can be rapidly set up to directly address certain experimental constraints. For example, in our screening for a fosmidomycin-related compound, we sought a compound

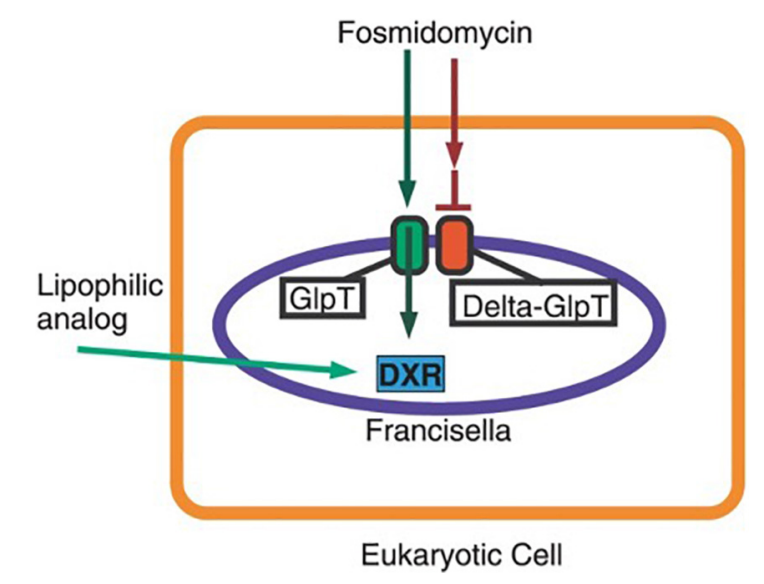

FIGURE 3 | Model for screening method to identify lipophilic, fosmidomycin-derived analogs effective against intracellular pathogens. Figure used under Creative Commons Attribution (CC BY 4.0) license (McKenney et al., 2012). In this system, the mammalian cell (orange line) is infected with intracellular bacteria (purple line), F. novicida (green GlpT protein), or F. novicida glpT mutant (red GlpT protein) separately. We demonstrated that the drug fosmidomycin is dependent on GlpT transporter to reach its intracellular target (DXR) in Francisella. This model demonstrates how we can use a mutant in a drug transporter in Francisella (blue cell) to screen for fosmidomycin analogs and prodrugs that act (i) independently of that transporter and (ii) are lipophilic and (iii) able to pass through both a bacterial membrane and (iv) a eukaryotic host cell membrane. Shown here is the difference between the parent compound fosmidomycin, which can pass through the host cell membrane, but requires Francisella GlpT to enter the bacteria, vs a lipophilic analog, which can pass through the host cell membrane and the bacterial cell membrane and can act on the drug target (DXR). The library of fosmidomycin analog candidates was first generated by testing candidate molecules against recombinant purified Francisella DXR in vitro (Jawaid et al., 2009). This intracellular model is constructed by infecting host cells with a glpT mutant of Francisella, and then screening a library of fosmidomycin analogs for inhibition of Francisella growth comparing the wild-type F. novicida vs the glpT mutant F. novicida for intracellular replication (123). whose antibacterial activity against intracellular Francisella was not dependent on the glpT transporter, which transported the non-lipophilic fosmidomycin prodrug into the bacterial cells. Infecting cells with a glpT transposon mutant of $F$. novicida, we were able to screen for compounds that inhibit Francisella intracellular growth without dependence on the bacterial glpT transporter for entry into the bacterium (Jawaid et al., 2009; McKenney et al., 2012). This screen applied the criteria of the drug being able to cross both the eukaryotic and the prokaryotic membrane, building in a powerful selection step in the screening method. This provided a very rapid, direct, and powerful screen for lipophilic versions of compounds that can act on intracellular Francisella in a glpT-independent manner, and for a compound which has the property of crossing both the eukaryotic and prokaryotic membranes as shown in Figure 3.

Research Question: What other antibiotics can affect the replication of intracellular Francisella? The intracellular nature of the infection should be emphasized when exploring antibiotic resistance or sensitivity of Francisella to new compounds.

\section{CONTRIBUTION OF ANTIBIOTIC RESISTANCE TO BACTERIAL FITNESS IN Francisella}

The possibility of either the natural or engineered emergence of AMR in the bacterial biothreat agents has always been of concern. Central to this concern is the fitness of organisms carrying such AMR characteristics and their ability to infect and replicate in the host. Recently, a study was undertaken by Biot et al. (2020) to assess the fitness of spontaneous ciprofloxacinand streptomycin-resistant $F$. novicida and F. holarctica LVS. Fitness was assessed through intracellular replication in host macrophages as well as through in vivo infection in mice. This study found that the ciprofloxacin-resistant strains in both parental backgrounds were attenuated in J774A.1 murine macrophage cells and caused no infection in BALB/c mice at any concentration of bacteria tested. This may reflect the stress that the DNA Gyrase mutations place upon the organism, which may be detrimental to its overall survival (and also affected biofilm production). In contrast, they demonstrated that the streptomycin-resistant strains in the LVS background were not significantly attenuated in macrophage cells (although more attenuated in the F. novicida background) and were attenuated in $\mathrm{BALB} / \mathrm{c}$ mice but still able to cause death, perhaps reflecting the lesser centrality of the streptomycin drug target in Francisella.

\section{CONCLUSION}

As new antibiotic development is exceedingly slow and Francisella is only susceptible to a few clinically relevant antibiotics, the continual monitoring of Francisella for enhanced or emerging AMR is essential. We have highlighted the many 
ways that Francisella resists current antimicrobials, as well as methods Francisella may employ to become more resistant to them. We also reviewed the new approaches to assessing the antimicrobial susceptibility of Francisella when it is intracellular, which may provide a relevant model for the in vivo situation. Areas of encouragement for further study were highlighted in Research Questions.

Drug development against all Gram-negative bacteria is an urgent need in light of the emerging AMR crisis, and work done of some of the more intractable and intracellular Gramnegative organisms should help identify novel antimicrobial agents which may prove effective against a broad range of pathogens.

\section{METHODS}

\section{Literature Search}

Google Scholar was used to search for original reports of genetic mechanisms of AMR in Francisella (1950 to November 2020). We focused on tularensis, holarctica, novicida, and hispaniensis sub-strains. Search phrases used included "antibiotic resistance," "multidrug resistant," "beta-lactam resistance," "polymyxin resistance," "erythromycin resistance," "macrolide resistance," "quinolone resistance," "fosmidomycin resistance," and "antibiotic resistance intracellular determination." All were appended to "Francisella." In addition, literature searches

\section{REFERENCES}

Abraham, E. P., Chain, E., Fletcher, C. M., Gardner, A. D., Heatley, N. G., Jennings, M. A., et al. (1941). Further observations on penicillin. Lancet 238, 177-189. doi: 10.1016/S0140-6736(00)72122-2

Ahlund, M. K., Ryden, P., Sjostedt, A., and Stoven, S. (2010). Directed screen of Francisella novicida virulence determinants using Drosophila melanogaster. Infect. Immun. 78, 3118-3128. doi: 10.1128/IAI.00146-10

Ahmad, S., Hunter, L., Qin, A., Mann, B. J., and van Hoek, M. L. (2010). Azithromycin effectiveness against intracellular infections of Francisella. BMC Microbiol. 10:123. doi: 10.1186/1471-2180-10-123

Akal $ı$ n, H., Helvacı, S., and Gedikoðlu, S. (2009). Re-emergence of tularemia in Turkey. Int. J. Infect. Dis. 13, 547-551. doi: 10.1016/j.ijid.2008.09.020

Alifano, P., Palumbo, C., Pasanisi, D., and Tala, A. (2015). Rifampicin-resistance, rpoB polymorphism and RNA polymerase genetic engineering. J. Biotechnol. 202, 60-77. doi: 10.1016/j.jbiotec.2014.11.024

Aloni-Grinstein, R., Schuster, O., Yitzhaki, S., Aftalion, M., Maoz, S., SteinbergerLevy, I., et al. (2017). Isolation of Francisella tularensis and Yersinia pestis from blood cultures by plasma purification and immunomagnetic separation accelerates antibiotic susceptibility determination. Front. Microbiol. 8:312. doi: 10.3389/fmicb. 2017.00312

Aloni-Grinstein, R., Shifman, O., Lazar, S., Steinberger-Levy, I., Maoz, S., and Ber, R. (2015). A rapid real-time quantitative PCR assay to determine the minimal inhibitory extracellular concentration of antibiotics against an intracellular Francisella tularensis live vaccine strain. Front. Microbiol. 6:1213. doi: 10.3389/ fmicb.2015.01213

Alqahtani, M., Ma, Z., Ketkar, H., Suresh, R. V., Malik, M., and Bakshi, C. S. (2018). Characterization of a unique outer membrane protein required for oxidative stress resistance and virulence of Francisella tularensis. J. Bacteriol. 200:e00693-17. doi: 10.1128/JB.00693-17

Amer, L. S., Bishop, B. M., and van Hoek, M. L. (2010). Antimicrobial and antibiofilm activity of Cathelicidins and short, synthetic peptides against Francisella. Biochem. Biophys. Res. Commun. 396, 246-251. doi: 10.1016/j.bbrc. 2010.04.073 through PubMed ${ }^{1}$ were done with the terms "Francisella" AND the relevant antibiotic AND "resistance." All genomic, proteomic, in vitro, in vivo, and intracellular growth data were considered.

\section{Database Search}

Uniprot $^{2}$ was used to identify groups of relevant genes or proteins in various Francisella strains. Pubmed Gene ${ }^{3}$ and Protein database ${ }^{4}$ searches were done with the terms "Francisella" AND the relevant antibiotic AND "resistance," or "Francisella" and "efflux pumps", or "Francisella" and "penicillin-binding proteins," etc. The KEGG genes database ${ }^{5}$ and the PGAT tool (Brittnacher et al., 2011) were also searched for similar terms. Each of these strategies was employed for each type of antibiotic resistance.

\section{AUTHOR CONTRIBUTIONS}

$\mathrm{MvH}$ conceived the study. SK and $\mathrm{MvH}$ wrote and edited the manuscript. Both authors approved the final version of the manuscript.

\footnotetext{
${ }^{1}$ ncbi.nlm.nih.gov

${ }^{2}$ http://www.uniprot.org

${ }^{3}$ https://www.ncbi.nlm.nih.gov/gene/

${ }^{4}$ https://www.ncbi.nlm.nih.gov/protein/

${ }^{5}$ https://www.kegg.jp/kegg/genes.html
}

Anthony, L. S., Gu, M. Z., Cowley, S. C., Leung, W. W., and Nano, F. E. (1991). Transformation and allelic replacement in Francisella spp. J. Gen. Microbiol. 137, 2697-2703. doi: 10.1099/00221287-137-12-2697

Antunes, N. T., Frase, H., Toth, M., and Vakulenko, S. B. (2012). The class A beta-lactamase FTU-1 is native to Francisella tularensis. Antimicrob. Agents Chemother. 56, 666-671. doi: 10.1128/AAC.05305-11

Aperis, G., Fuchs, B. B., Anderson, C. A., Warner, J. E., Calderwood, S. B., and Mylonakis, E. (2007). Galleria mellonella as a model host to study infection by the Francisella tularensis live vaccine strain. Microbes Infect. 9, 729-734. doi: 10.1016/j.micinf.2007.02.016

Asare, R., and Abu Kwaik, Y. (2010). Molecular complexity orchestrates modulation of phagosome biogenesis and escape to the cytosol of macrophages by Francisella tularensis. Environ. Microbiol. 12, 2559-2586. doi: 10.1111/j. 1462-2920.2010.02229.x

Baker, C. N., Hollis, D. G., and Thornsberry, C. (1985). Antimicrobial susceptibility testing of Francisella tularensis with a modified Mueller-Hinton broth. J. Clin. Microbiol. 22, 212-215. doi: 10.1128/JCM.22.2.212-215.1985

Baldwin, J., Urban, F., Cooper, R., and Jose, F. (1973). Direct 6-methoxylation of penicillin derivatives. Convenient pathway to substituted. beta.-lactam antibiotics. J. Am. Chem. Soc. 95, 2401-2403. doi: 10.1021/ja0078 $8 \mathrm{a} 071$

Band, V. I., and Weiss, D. S. (2015). Mechanisms of antimicrobial peptide resistance in Gram-Negative bacteria. Antibiotics (Basel) 4, 18-41. doi: 10.3390/ antibiotics 4010018

Baron, G. S., Myltseva, S. V., and Nano, F. E. (1995). Electroporation of Francisella tularensis. Methods Mol. Biol. 47, 149-154. doi: 10.1385/0-89603-310-4:149

Bhatnagar, N., Getachew, E., Straley, S., Williams, J., Meltzer, M., and Fortier, A. (1994). Reduced virulence of rifampicin-resistant mutants of Francisella tularensis. J. Infect. Dis. 170, 841-847. doi: 10.1093/infdis/170. 4.841

Bina, X. R., Lavine, C. L., Miller, M. A., and Bina, J. E. (2008). The AcrAB RND efflux system from the live vaccine strain of Francisella tularensis is a multiple drug efflux system that is required for virulence in mice. FEMS Microbiol. Lett. 279, 226-233. doi: 10.1111/j.1574-6968.2007.01033.x 
Bina, X. R., Wang, C., Miller, M. A., and Bina, J. E. (2006). The Bla2 $\beta$-lactamase from the live-vaccine strain of Francisella tularensis encodes a functional protein that is only active against penicillin-class $\beta$-lactam antibiotics. Arch. Microbiol. 186, 219-228. doi: 10.1007/s00203-006-0140-6

Biot, F. V., Bachert, B. A., Mlynek, K. D., Toothman, R. G., Koroleva, G. I., Lovett, S. P., et al. (2020). Evolution of antibiotic resistance in surrogates of Francisella tularensis (LVS and Francisella novicida): effects on biofilm formation and fitness. Front. Microbiol. 11:593542. doi: 10.3389/fmicb.2020.593542

Biswas, S., Raoult, D., and Rolain, J. M. (2008). A bioinformatic approach to understanding antibiotic resistance in intracellular bacteria through whole genome analysis. Int. J. Antimicrob. Agents. 32, 207-220. doi: 10.1016/j. ijantimicag.2008.03.017

Bodey, G. P. (1990). Penicillins, monobactams, and carbapenems. Tex. Heart Inst. J. 17, 315-329.

Boisset, S., Caspar, Y., Sutera, V., and Maurin, M. (2014). New therapeutic approaches for treatment of tularaemia: a review. Front. Cell. Infect. Microbiol. 4:40. doi: 10.3389/fcimb.2014.00040

Bosio, C. M., and Dow, S. W. (2005). Francisella tularensis induces aberrant activation of pulmonary dendritic cells. J. Immunol. 175, 6792-6801. doi: 10.4049/jimmunol.175.10.6792

Brett, M. E., Respicio-Kingry, L. B., Yendell, S., Ratard, R., Hand, J., Balsamo, G., et al. (2014). Outbreak of Francisella novicida bacteremia among inmates at a Louisiana correctional facility. Clin. Infect. Dis. 59, 826-833. doi: 10.1093/cid/ ciu430

Brittnacher, M. J., Fong, C., Hayden, H. S., Jacobs, M. A., Radey, M., and Rohmer, L. (2011). PGAT: a multistrain analysis resource for microbial genomes. Bioinformatics 27, 2429-2430. doi: 10.1093/bioinformatics/btr418

Brodmann, M., Heilig, R., Broz, P., and Basler, M. (2018). Mobilizable plasmids for tunable gene expression in Francisella novicida. Front. Cell. Infect. Microbiol. 8:284. doi: $10.3389 /$ fcimb.2018.00284

Buchan, B. W., McLendon, M. K., and Jones, B. D. (2008). Identification of differentially regulated francisella tularensis genes by use of a newly developed Tn5-based transposon delivery system. Appl. Environ. Microbiol. 74, 26372645. doi: 10.1128/AEM.02882-07

Caspar, Y., and Maurin, M. (2017). Francisella tularensis susceptibility to antibiotics: a comprehensive review of the data obtained in vitro and in animal models. Front. Cell. Infect. Microbiol. 7:122. doi: 10.3389/fcimb.2017. 00122

Caspar, Y., Siebert, C., Sutera, V., Villers, C., Aubry, A., Mayer, C., et al. (2017). Functional characterization of the DNA gyrases in fluoroquinolone-resistant mutants of Francisella novicida. Antimicrob. Agents Chemother. 61:e02277-16. doi: 10.1128/AAC.02277-16

Chain, E. (1979). The early years of the penicillin discovery. Trends Pharmacol. Sci. 1, 6-11. doi: 10.1016/0165-6147(79)90004-X

Challacombe, J. F., Pillai, S., and Kuske, C. R. (2017). Shared features of cryptic plasmids from environmental and pathogenic Francisella species. PLoS One. 12:e0183554. doi: 10.1371/journal.pone.0183554

Champion, A. E., Catanzaro, K. C. F., Bandara, A. B., and Inzana, T. J. (2019). Formation of the Francisella tularensis biofilm is affected by cell surface glycosylation, growth medium, and a glucan exopolysaccharide. Sci. Rep. 9:12252. doi: 10.1038/s41598-019-48697-x

Chen, L. F., and Kaye, D. (2011). Current use for old antibacterial agents: polymyxins, rifamycins, and aminoglycosides. Med. Clin. North Am. 95, 81942,viii-ix. doi: 10.1016/j.mcna.2011.03.007

Chopra, I. (2010). “Chapter 2-Modes of Action in Antibiotic And Chemotherapy, eds R. G. Finch, D. Greenwood, S. R. Norrby, and R. J. Whitley (W.B. Saunders), 10-23. doi: 10.1016/B978-0-7020-4064-1.00070-1

Chung, M. C., Dean, S., Marakasova, E. S., Nwabueze, A. O., and van Hoek, M. L. (2014). Chitinases are negative regulators of Francisella novicida biofilms. PLoS One 9:e93119. doi: 10.1371/journal.pone.0093119

Chung, M. C., Dean, S. N., and van Hoek, M. L. (2015). Acyl carrier protein is a bacterial cytoplasmic target of cationic antimicrobial peptide LL-37. Biochem. J. 470, 243-253. doi: 10.1042/BJ20150432

CIDRAP. (2013). Tularemia; Treatment, Postexposure Prophylaxis, and Vaccines. Minneapolis, MN: CIDRAP

Coates, S. J., Briggs, B., and Cordoro, K. M. (2018). Tularemia-induced erythema multiforme minor in an 11-year-old girl. Pediatr. Dermatol. 35, 478-481. doi: $10.1111 /$ pde. 13501
Conlan, J. W., and North, R. J. (1992). Early pathogenesis of infection in the liver with the facultative intracellular bacteria Listeria monocytogenes, Francisella tularensis, and Salmonella typhimurium involves lysis of infected hepatocytes by leukocytes. Infect. Immun. 60, 5164-5171. doi: 10.1128/IAI.60.12.5164-5171. 1992

Cowley, S. C., Myltseva, S. V., and Nano, F. E. (1997). Suppression of Francisella tularensis growth in the rat by co-infection with $F$. novicida. FEMS Microbiol. Lett. 153, 71-74. doi: 10.1111/j.1574-6968.1997.tb1 0465.x

Cross, J. T., and Jacobs, R. F. (1993). Tularemia: treatment failures with outpatient use of ceftriaxone. Clin. Infect. Dis. 17, 976-980. doi: 10.1093/clinids/17.6.976

Dean, R. E., Ireland, P. M., Jordan, J. E., Titball, R. W., and Oyston, P. C. F. (2009). RelA regulates virulence and intracellular survival of Francisella novicida. Microbiology (Reading) 155(Pt 12), 4104-4113. doi: 10.1099/mic.0.031021-0

Dean, S. N., Chung, M. C., and van Hoek, M. L. (2015). Burkholderia diffusible signal factor signals to Francisella novicida to disperse biofilm and increase siderophore production. Appl. Environ. Microbiol. 81, 7057-7066. doi: 10.1128/ AEM.02165-15

Dean, S. N., Milton, M. E., Cavanagh, J., and van Hoek, M. L. (2020). Francisella novicida two-component system response regulator $\mathrm{BfpR}$ modulates iglC gene expression, antimicrobial peptide resistance, and biofilm production. Front. Cell. Infect. Microbiol. 10:82. doi: 10.3389/fcimb.2020.00082

Dean, S. N., and van Hoek, M. L. (2015). Screen of FDA-approved drug library identifies maprotiline, an antibiofilm and antivirulence compound with QseC sensor-kinase dependent activity in Francisella novicida. Virulence 6, 487-503. doi: 10.1080/21505594.2015.1046029

Dennis, D. T., Inglesby, T. V., Henderson, D. A., Bartlett, J. G., Ascher, M. S., Eitzen, E., et al. (2001). Tularemia as a biological weapon: medical and public health management. JAMA 285, 2763-2773. doi: 10.1001/jama.285.21.2763

Djainal, W. A. S., Shahin, K., Metselaar, M., Adams, A., and Desbois, A. P. (2020). Larva of greater wax moth Galleria mellonella is a suitable alternative host for the fish pathogen Francisella noatunensis subsp. orientalis. BMC Microbiol. 20:8. doi: 10.1186/s12866-020-1695-0

Drocourt, D., Calmels, T., Reynes, J. P., Baron, M., and Tiraby, G. (1990). Cassettes of the Streptoalloteichus hindustanus ble gene for transformation of lower and higher eukaryotes to phleomycin resistance. Nucleic Acids Res. 18:4009. doi: 10.1093/nar/18.13.4009

Dupont, E., Van Eeckhoudt, S., Thissen, X., Ausselet, N., Fretin, D., Stefanescu, I., et al. (2015). About three cases of ulceroglandular tularemia, is this the reemergence of Francisella tularensis in Belgium? Acta Clin. Belg. 70, 364-368. doi: 10.1179/2295333715Y.0000000022

Durham-Colleran, M. W., Verhoeven, A. B., and van Hoek, M. L. (2010). Francisella novicida forms in vitro biofilms mediated by an orphan response regulator. Microb. Ecol. 59, 457-465. doi: 10.1007/s00248-009-9586-9

Edwards, E. I., Epton, R., and Marr, G. (1975). Organometallic derivatives of penicillins and cephalosporins a new class of semi-synthetic antibiotics. J. Organomet. Chem. 85, C23-C25. doi: 10.1016/S0022-328X(00)80708-1

Eklund, B. E., Mahdi, O., Huntley, J. F., Collins, E., Martin, C., Horzempa, J., et al. (2017). The orange spotted cockroach (Blaptica dubia, Serville 1839) is a permissive experimental host for Francisella tularensis. Proc. W. Va. Acad. Sci. 89, 34-47. doi: 10.7287/peerj.preprints. 1524

Eliasson, H., Lindbäck, J., Nuorti, J. P., Arneborn, M., Giesecke, J., and Tegnell, A. (2002). The 2000 tularemia outbreak: a case-control study of risk factors in disease-endemic and emergent areas, Sweden. Emerg. Infect. Dis. 8, 956-960. doi: 10.3201/eid0809.020051

Enderlin, G., Morales, L., Jacobs, R. F., and Cross, J. T. (1994). Streptomycin and alternative agents for the treatment of tularemia: review of the literature. Clin. Infect. Dis. 19, 42-47. doi: 10.1093/clinids/19.1.42

Enstrom, M., Held, K., Ramage, B., Brittnacher, M., Gallagher, L., and Manoil, C. (2012). Genotype-phenotype associations in a nonmodel prokaryote. mBio 3:e00001-12. doi: 10.1128/mBio.00001-12

Findlay, F., Proudfoot, L., Stevens, C., and Barlow, P. G. (2016). Cationic host defense peptides; novel antimicrobial therapeutics against Category A pathogens and emerging infections. Pathog. Glob. Health 110, 137-147. doi: 10.1080/20477724.2016.1195036

Fleming, A. (1929). On the antibacterial action of cultures of a penicillium, with special reference to their use in the isolation of B. influenzae. Br. J. Exp. Pathol. 10:226. 
Flick-Smith, H. C., Fox, M. A., Hamblin, K. A., Richards, M. I., Jenner, D. C., Laws, T. R., et al. (2013). Assessment of antimicrobial peptide LL-37 as a postexposure therapy to protect against respiratory tularemia in mice. Peptides 43 , 96-101. doi: 10.1016/j.peptides.2013.02.024

Forsberg, K. J., Reyes, A., Wang, B., Selleck, E. M., Sommer, M. O., and Dantas, G. (2012). The shared antibiotic resistome of soil bacteria and human pathogens. Science 337, 1107-1111. doi: 10.1126/science.1220761

Foshay, L., and Pasternack, A. B. (1946). Streptomycin treatment of tularemia. J. Am. Med. Assoc. 130, 393-398. doi: 10.1001/jama.1946.02870070013004

Frank, D. W., and Zahrt, T. C. (2007). Genetics and genetic manipulation in Francisella tularensis. Ann. N. Y. Acad. Sci. 1105, 67-97. doi: 10.1196/annals. 1409.008

Fu, H. L., Meng, Y., Ordonez, E., Villadangos, A. F., Bhattacharjee, H., Gil, J. A., et al. (2009). Properties of arsenite efflux permeases (Acr3) from Alkaliphilus metalliredigens and Corynebacterium glutamicum. J. Biol. Chem. 284, 1988719895. doi: 10.1074/jbc.M109.011882

Gallagher, L. A., Ramage, E., Jacobs, M. A., Kaul, R., Brittnacher, M., and Manoil, C. (2007). A comprehensive transposon mutant library of Francisella novicida, a bioweapon surrogate. Proc. Natl. Acad. Sci. U. S. A. 104, 1009-1014. doi: 10.1073/pnas.0606713104

Garcia del Blanco, N., Gutierrez Martin, C. B., de la Puente Redondo, V. A., and Rodriguez Ferri, E. F. (2004). In vitro susceptibility of field isolates of Francisella tularensis subsp. holarctica recovered in Spain to several antimicrobial agents. Res. Vet. Sci. 76, 195-198. doi: 10.1016/j.rvsc.2003.12.002

Gentry, M., Taormina, J., Pyles, R. B., Yeager, L., Kirtley, M., Popov, V. L., et al. (2007). Role of primary human alveolar epithelial cells in host defense against Francisella tularensis infection. Infect. Immun. 75, 3969-3978. doi: 10.1128/IAI. 00157-07

Gestin, B., Valade, E., Thibault, F., Schneider, D., and Maurin, M. (2010). Phenotypic and genetic characterization of macrolide resistance in Francisella tularensis subsp. holarctica biovar I. J. Antimicrob. Chemother. 65, 2359-2367. doi: $10.1093 / \mathrm{jac} / \mathrm{dkq} 315$

Ghosh, D., Veeraraghavan, B., Elangovan, R., and Vivekanandan, P. (2020). Antibiotic resistance and epigenetics: more to it than meets the eye. Antimicrob. Agents Chemother. 64:e02225-19. doi: 10.1128/AAC.02225-19

Gil, H., Platz, G. J., Forestal, C. A., Monfett, M., Bakshi, C. S., Sellati, T. J., et al. (2006). Deletion of TolC orthologs in Francisella tularensis identifies roles in multidrug resistance and virulence. Proc. Natl. Acad. Sci. U.S.A. 103, 12897-12902. doi: 10.1073/pnas.0602582103

Golovliov, I., Ericsson, M., Sandstrom, G., Tarnvik, A., and Sjostedt, A. (1997). Identification of proteins of Francisella tularensis induced during growth in macrophages and cloning of the gene encoding a prominently induced 23kilodalton protein. Infect. Immun. 65, 2183-2189. doi: 10.1128/IAI.65.6.21832189.1997

Golovliov, I., Sjostedt, A., Mokrievich, A., and Pavlov, V. (2003). A method for allelic replacement in Francisella tularensis. FEMS Microbiol. Lett. 222, 273-280. doi: 10.1016/S0378-1097(03)00313-6

Gunn, J. S., and Ernst, R. K. (2007). The structure and function of Francisella lipopolysaccharide. Ann. N. Y. Acad. Sci. 1105, 202-218. doi: 10.1196/annals. 1409.006

Gupta, K., Singh, S., and van Hoek, M. L. (2015). Short, synthetic cationic peptides have antibacterial activity against Mycobacterium smegmatis by forming pores in membrane and synergizing with antibiotics. Antibiotics (Basel) 4, 358-378. doi: 10.3390/antibiotics4030358

Hall, J. D., Craven, R. R., Fuller, J. R., Pickles, R. J., and Kawula, T. H. (2007). Francisella tularensis replicates within alveolar type II epithelial cells in vitro and in vivo following inhalation. Infect. Immun. 75, 1034-1039. doi: 10.1128/ IAI.01254-06

Han, S., Bishop, B. M., and van Hoek, M. L. (2008). Antimicrobial activity of human beta-defensins and induction by Francisella. Biochem. Biophys. Res. Commun. 371, 670-674. doi: 10.1016/j.bbrc.2008.04.092

Haynes, M. K., Garcia, M., Peters, R., Waller, A., Tedesco, P., Ursu, O., et al. (2018). "Chapter 16, high-throughput flow cytometry screening of multidrug efflux systems," in Bacterial Multidrug Exporters Methods and Protocols, eds A. Yamaguchi and K. Nishino (Humana Press). doi: 10.1007/978-1-4939-7454-2

Heine, H. S., Miller, L., Halasohoris, S., and Purcell, B. K. (2017). In vitro antibiotic susceptibilities of Francisella tularensis determined by broth microdilution following CLSI methods. Antimicrob. Agents Chemother. 61:e00612-17. doi: 10.1128/AAC.00612-17

Horzempa, J., Carlson, P. E., O’Dee, D. M., Shanks, R. M., and Nau, G. J. (2008). Global transcriptional response to mammalian temperature provides new insight into Francisella tularensis pathogenesis. BMC microbiology 8:172. doi: 10.1186/1471-2180-8-172

Hotta, A., Fujita, O., Uda, A., Sharma, N., Tanabayashi, K., Yamamoto, Y., et al. (2013). In vitro antibiotic susceptibility of Francisella tularensis isolates from Japan. Jpn. J. Infect. Dis. 66, 534-536. doi: 10.7883/yoken.66.534

Hotta, A., Sharma, N., Fujita, O., Uda, A., Tanabayashi, K., Tian, D., et al. (2020). Virulence of Francisella tularensis Subspecies holarctica Biovar japonica and phenotypic change during serial passages on artificial media. Microorganisms 8:1881. doi: 10.3390/microorganisms8121881

Humrighouse, B., Adcock, N., and Rice, E. (2011). Use of acid treatment and a selective medium to enhance the recovery of Francisella tularensis from water. Appl. Environ. Microbiol. 77, 6729-6732. doi: 10.1128/AEM.05226-11

Huovinen, P. (2001). Resistance to trimethoprim-sulfamethoxazole. Clin. Infect. Dis. 32, 1608-1614. doi: 10.1086/320532

Ikaheimo, I., Syrjala, H., Karhukorpi, J., Schildt, R., and Koskela, M. (2000). In vitro antibiotic susceptibility of Francisella tularensis isolated from humans and animals. J. Antimicrob. Chemother. 46, 287-290. doi: 10.1093/jac/46. 2.287

Isberg, R. R., and Falkow, S. (1985). A single genetic locus encoded by Yersinia pseudotuberculosis permits invasion of cultured animal cells by Escherichia coli K-12. Nature 317, 262-264. doi: 10.1038/317262a0

Jaing, C. J., McLoughlin, K. S., Thissen, J. B., Zemla, A., Gardner, S. N., Vergez, L. M., et al. (2016). Identification of genome-wide mutations in ciprofloxacinresistant $F$. tularensis LVS using whole genome tiling arrays and next generation sequencing. PLoS One 11:e0163458. doi: 10.1371/journal.pone.0163458

Jawaid, S., Seidle, H., Zhou, W., Abdirahman, H., Abadeer, M., Hix, J. H., et al. (2009). Kinetic characterization and phosphoregulation of the Francisella tularensis 1-deoxy-D-xylulose 5-phosphate reductoisomerase (MEP synthase). PLoS One 4:e8288. doi: 10.1371/journal.pone.0008288

Joo, S. H., and Chung, H. S. (2016). Crystal structure and activity of Francisella novicida UDP-N-acetylglucosamine acyltransferase. Biochem. Biophys. Res. Commun. 478, 1223-1229. doi: 10.1016/j.bbrc.2016.08.098

Juan, C., Torrens, G., Gonzalez-Nicolau, M., and Oliver, A. (2017). Diversity and regulation of intrinsic beta-lactamases from non-fermenting and other Gram-negative opportunistic pathogens. FEMS Microbiol. Rev. 41, 781-815. doi: 10.1093/femsre/fux043

Karlsson, E., Golovliov, I., Larkeryd, A., Granberg, M., Larsson, E., Ohrman, C., et al. (2016). Clonality of erythromycin resistance in Francisella tularensis. J. Antimicrob. Chemother. 71, 2815-2823. doi: 10.1093/jac/dkw235

Kaushal, A., Gupta, K., Shah, R., and van Hoek, M. L. (2016). Antimicrobial activity of mosquito cecropin peptides against Francisella. Dev. Comp. Immunol. 63, 171-180. doi: 10.1016/j.dci.2016.05.018

Kearse, M., Moir, R., Wilson, A., Stones-Havas, S., Cheung, M., Sturrock, S., et al. (2012). Geneious Basic: an integrated and extendable desktop software platform for the organization and analysis of sequence data. Bioinformatics. 28, 1647-1649. doi: 10.1093/bioinformatics/bts199

KEGG (2020). Cationic Antimicrobial Peptide (CAMP) Resistance-Francisella tularensis Subsp. tularensis SCHU S4. Available online at: https://www.genome. jp/kegg-bin/show_pathway?ftu01503 (accessed June 15, 2020).

Klimpel, G. R., Eaves-Pyles, T., Moen, S. T., Taormina, J., Peterson, J. W., Chopra, A. K., et al. (2008). Levofloxacin rescues mice from lethal intra-nasal infections with virulent Francisella tularensis and induces immunity and production of protective antibody. Vaccine 26, 6874-6882. doi: 10.1016/j.vaccine.2008.09.077

Knowles, J. R. (1985). Penicillin resistance: the chemistry of. beta.-lactamase inhibition. Accounts Chem. Res. 18, 97-104. doi: 10.1021/ar0011 $2 \mathrm{a} 001$

Koliaditskaia, L. S., Kuchina, K. V., and Shmurygina, A. A. (1959). [Tularemia bacteriophage; preliminary communication]. Zh. Mikrobiol. Epidemiol. Immunobiol. 30, 13-17.

Kopping, E. J., Doyle, C. R., Sampath, V., and Thanassi, D. G. (2019). Contributions of TolC orthologs to Francisella tularensis Schu S4 multidrug resistance, modulation of host cell responses, and virulence. Infect. Immun. 87:e00823-18. doi: 10.1128/IAI.00823-18 
Kormilitsyna, M. I., and Marakusha, B. I. (1983). [Biological characteristics of spectinomycin-resistant strains of the tularemia pathogen]. Antibiotiki 28, $434-436$.

Kraemer, P. S., Mitchell, A., Pelletier, M. R., Gallagher, L. A., Wasnick, M., Rohmer, L., et al. (2009). Genome-wide screen in Francisella novicida for genes required for pulmonary and systemic infection in mice. Infect. Immun. 77, 232-244. doi: 10.1128/IAI.00978-08

Kudelina, R., and Olsufiev, N. (1980). Sensitivity to macrolide antibiotics and lincomycin in Francisella tularensis holarctica. J. Hyg. Epidemiol. Microbiol. Immunol. 24, 84-91.

Kumar, A., Mayo, M., Trunck, L. A., Cheng, A. C., Currie, B. J., and Schweizer, H. P. (2008). Expression of resistance-nodulation-cell-division efflux pumps in commonly used Burkholderia pseudomallei strains and clinical isolates from northern Australia. Trans. R. Soc. Trop. Med. Hyg. 102(Suppl. 1), S145-S151. doi: 10.1016/S0035-9203(08)70032-4

Lai, X. H., Shirley, R. L., Crosa, L., Kanistanon, D., Tempel, R., Ernst, R. K., et al. (2010). Mutations of Francisella novicida that alter the mechanism of its phagocytosis by murine macrophages. PLoS One 5:e11857. doi: 10.1371/ journal.pone.0011857

Larsson, P., Oyston, P. C., Chain, P., Chu, M. C., Duffield, M., Fuxelius, H. H., et al. (2005). The complete genome sequence of Francisella tularensis, the causative agent of tularemia. Nat. Genet. 37, 153-159. doi: 10.1038/ng 1499

Lee, C. R., Lee, J. H., Park, M., Park, K. S., Bae, I. K., Kim, Y. B., et al. (2017). Biology of Acinetobacter baumannii: pathogenesis, antibiotic resistance mechanisms, and prospective treatment options. Front. Cell. Infect. Microbiol. 7:55. doi: 10.3389/fcimb.2017.00055

Li, Y., Powell, D. A., Shaffer, S. A., Rasko, D. A., Pelletier, M. R., Leszyk, J. D., et al. (2012). LPS remodeling is an evolved survival strategy for bacteria. Proc. Natl. Acad. Sci. U.S.A. 109, 8716-8721. doi: 10.1073/pnas.1202908109

Lindgren, H., and Sjostedt, A. (2016). Gallium potentiates the antibacterial effect of gentamicin against Francisella tularensis. Antimicrob. Agents Chemother. 60, 288-295. doi: 10.1128/AAC.01240-15

Lindquist, S., Weston-Hafer, K., Schmidt, H., Pul, C., Korfmann, G., Erickson, J., et al. (1993). AmpG, a signal transducer in chromosomal beta-lactamase induction. Mol. Microbiol. 9, 703-715. doi: 10.1111/j.1365-2958.1993.tb01731.x

Llewellyn, A. C., Zhao, J., Song, F., Parvathareddy, J., Xu, Q., Napier, B. A., et al. (2012). NaxD is a deacetylase required for lipid A modification and Francisella pathogenesis. Mol. Microbiol. 86, 611-627. doi: 10.1111/mmi.12004

Lomovskaya, O., and Lewis, K. (1992). Emr, an Escherichia coli locus for multidrug resistance. Proc. Natl. Acad. Sci. 89, 8938-8942. doi: 10.1073/pnas.89.19.8938

Loughman, K., Hall, J., Knowlton, S., Sindeldecker, D., Gilson, T., Schmitt, D. M., et al. (2016). Temperature-dependent gentamicin resistance of Francisella tularensis is mediated by uptake modulation. Front. Microbiol. 7:37. doi: 10 . 3389/fmicb.2016.00037

LoVullo, E. D., Miller, C. N., Pavelka, M. S. Jr., and Kawula, T. H. (2012). TetR-based gene regulation systems for Francisella tularensis. Appl. Environ. Microbiol. 78, 6883-6889. doi: 10.1128/AEM.01679-12

Ludu, J. S., Nix, E. B., Duplantis, B. N., de Bruin, O. M., Gallagher, L. A., Hawley, L. M., et al. (2008). Genetic elements for selection, deletion mutagenesis and complementation in Francisella spp. FEMS Microbiol. Lett. 278, 86-93. doi: 10.1111/j.1574-6968.2007.00979.x

Ma, Z., Banik, S., Rane, H., Mora, V. T., Rabadi, S. M., Doyle, C. R., et al. (2014). EmrA 1 membrane fusion protein of Francisella tularensis LVS is required for resistance to oxidative stress, intramacrophage survival and virulence in mice. Mol. Microbiol. 91, 976-995. doi: 10.1111/mmi.12509

Mackie, R. S., McKenney, E. S., and van Hoek, M. L. (2012). Resistance of Francisella novicida to fosmidomycin associated with mutations in the glycerol3-phosphate transporter. Front. Microbiol. 3:226. doi: 10.3389/fmicb.2012. 00226

Majiduddin, F. K., Materon, I. C., and Palzkill, T. G. (2002). Molecular analysis of beta-lactamase structure and function. Int. J. Med. Microbiol. 292, 127-137. doi: 10.1078/1438-4221-00198

Manavathu, E. K., Fernandez, C. L., Cooperman, B. S., and Taylor, D. E. (1990). Molecular studies on the mechanism of tetracycline resistance mediated by Tet(O). Antimicrob. Agents Chemother. 34, 71-77. doi: 10.1128/AAC. 34.1.71
Margolis, J. J., El-Etr, S., Joubert, L. M., Moore, E., Robison, R., Rasley, A., et al. (2010). Contributions of Francisella tularensis subsp. novicida chitinases and Sec secretion system to biofilm formation on chitin. Appl. Environ. Microbiol. 76, 596-608. doi: 10.1128/AEM.02037-09

Marinov, K. T., Georgieva, E. D., Ivanov, I. N., and Kantardjiev, T. V. (2009). Characterization and genotyping of strains of Francisella tularensis isolated in Bulgaria. J. Med. Microbiol. 58(Pt 1), 82-85. doi: 10.1099/jmm.0. 003426-0

Maslow, M. J., and Portal-Celhay, C. (2015). "Rifamycins," in Mandell, Douglas, and Bennett's Principles and Practice of Infectious Diseases, 8th Edn, eds J. E. Bennett, R. Dolin, and M. J. Blaser (London: Churchill Livingstone Elsevier), 339-49.e3. doi: 10.1016/B978-1-4557-4801-3.00027-8

Maurin, M., Mersali, N. F., and Raoult, D. (2000). Bactericidal activities of antibiotics against intracellular Francisella tularensis. Antimicrob. Agents Chemother. 44, 3428-3431. doi: 10.1128/AAC.44.12.3428-3431.2000

McKenney, E. S., Sargent, M., Khan, H., Uh, E., Jackson, E. R., San Jose, G., et al. (2012). Lipophilic prodrugs of FR900098 are antimicrobial against Francisella novicida in vivo and in vitro and show GlpT independent efficacy. PLoS One 7:e38167. doi: 10.1371/journal.pone.0038167

McWhinnie, R. L., and Nano, F. E. (2014). Synthetic promoters functional in Francisella novicida and Escherichia coli. Appl. Environ. Microbiol. 80, 226-234. doi: 10.1128/AEM.02793-13

Moule, M. G., Monack, D. M., and Schneider, D. S. (2010). Reciprocal analysis of Francisella novicida infections of a Drosophila melanogaster model reveal host-pathogen conflicts mediated by reactive oxygen and imd-regulated innate immune response. PLoS Pathog. 6:e1001065. doi: 10.1371/journal.ppat. 1001065

Munita, J. M., and Arias, C. A. (2016). Mechanisms of antibiotic resistance. Microbiol. Spectr. 4:0016-2015. doi: 10.1128/microbiolspec.VMBF-0016-2015

Naas, T., Dortet, L., and Iorga, B. I. (2016). Structural and functional aspects of class A Carbapenemases. Curr. Drug Targets 17, 1006-1028. doi: 10.2174/ 1389450117666160310144501

Nadar, V. S., Chen, J., Dheeman, D. S., Galvan, A. E., Yoshinaga-Sakurai, K., Kandavelu, P., et al. (2019). Arsinothricin, an arsenic-containing nonproteinogenic amino acid analog of glutamate, is a broad-spectrum antibiotic. Commun. Biol. 2:131. doi: 10.1038/s42003-019-0365-y

Nelson, M., Lever, M. S., Dean, R. E., Pearce, P. C., Stevens, D. J., and Simpson, A. J. (2010). Bioavailability and efficacy of levofloxacin against Francisella tularensis in the common marmoset (Callithrix jacchus). Antimicrob. Agents Chemother. 54, 3922-3926. doi: 10.1128/AAC.00390-10

Okan, N. A., and Kasper, D. L. (2013). The atypical lipopolysaccharide of Francisella. Carbohydr. Res. 378, 79-83. doi: 10.1016/j.carres.2013.06.015

Pavlov, V. M., Mokrievich, A. N., and Volkovoy, K. (1996). Cryptic plasmid pFNL10 from Francisella novicida-like F6168: the base of plasmid vectors for Francisella tularensis. FEMS Immunol. Med. Microbiol. 13, 253-256. doi: 10. 1111/j.1574-695X.1996.tb00247.x

Pavlovich, N. V., and Tsimbalistova, M. V. (2019). Increased antibacterial activity of cephalosporins against Francisella tularensis. Antibiot. Chemother. 64, 8-12.

Perez-Castrillon, J. L., Bachiller-Luque, P., Martin-Luquero, M., Mena-Martin, F. J., and Herreros, V. (2001). Tularemia epidemic in northwestern Spain: clinical description and therapeutic response. Clin. Infect. Dis. 33, 573-576. doi: $10.1086 / 322601$

Petersen, J. M., Carlson, J., Yockey, B., Pillai, S., Kuske, C., Garbalena, G., et al. (2009). Direct isolation of Francisella spp. from environmental samples. Lett. Appl. Microbiol. 48, 663-667. doi: 10.1111/j.1472-765X.2009.02589.x

Petersen, J. M., Schriefer, M. E., Carter, L. G., Zhou, Y., Sealy, T., Bawiec, D., et al. (2004a). Laboratory analysis of tularemia in wild-trapped, commercially traded prairie dogs, Texas, 2002. Emerg. Infect. Dis. 10, 419-425. doi: 10.3201/eid1003. 030504

Petersen, J. M., Schriefer, M. E., Gage, K. L., Montenieri, J. A., Carter, L. G., Stanley, M., et al. (2004b). Methods for enhanced culture recovery of Francisella tularensis. Appl. Environ. Microbiol. 70, 3733-3735. doi: 10.1128/AEM.70.6. 3733-3735.2004

Peterson, J. W., Moen, S. T., Healy, D., Pawlik, J. E., Taormina, J., Hardcastle, J., et al. (2010). Protection afforded by fluoroquinolones in animal models of respiratory infections with Bacillus anthracis, Yersinia pestis, and Francisella tularensis. Open Microbiol. J. 4, 34-46. doi: 10.2174/1874285801004010034 
Petrosino, J. F., Xiang, Q., Karpathy, S. E., Jiang, H., Yerrapragada, S., Liu, Y., et al. (2006). Chromosome rearrangement and diversification of Francisella tularensis revealed by the type B (OSU18) genome sequence. J. Bacteriol. 188, 6977-6985. doi: 10.1128/JB.00506-06

Phillips, N. J., Schilling, B., McLendon, M. K., Apicella, M. A., and Gibson, B. W. (2004). Novel modification of lipid A of Francisella tularensis. Infect. Immun. 72, 5340-5348. doi: 10.1128/IAI.72.9.5340-5348.2004

Pomerantsev, A. P., Golovliov, I. R., Ohara, Y., Mokrievich, A. N., Obuchi, M., Norqvist, A., et al. (2001a). Genetic organization of the Francisella plasmid pFNL10. Plasmid 46, 210-222. doi: 10.1006/plas.2001.1548

Pomerantsev, A. P., Obuchi, M., and Ohara, Y. (2001b). Nucleotide sequence, structural organization, and functional characterization of the small recombinant plasmid pOM1 that is specific for Francisella tularensis. Plasmid 46, 86-94. doi: 10.1006/plas.2001.1538

Propst, C. N., Nwabueze, A. O., Kanev, I. L., Pepin, R. E., Gutting, B. W., Morozov, V. N., et al. (2016a). Nanoaerosols reduce required effective dose of liposomal levofloxacin against pulmonary murine Francisella tularensis subsp. novicida infection. J. Nanobiotechnol. 14:29. doi: 10.1186/s12951-016-0182-0

Propst, C. N., Pylypko, S. L., Blower, R. J., Ahmad, S., Mansoor, M., and van Hoek, M. L. (2016b). Francisella philomiragia infection and lethality in mammalian tissue culture cell models, Galleria mellonella, and BALB/c Mice. Front. Microbiol. 7:696. doi: 10.3389/fmicb.2016.00696

Reintjes, R., Dedushaj, I., Gjini, A., Jorgensen, T. R., Cotter, B., Lieftucht, A., et al. (2002). Tularemia outbreak investigation in Kosovo: case control and environmental studies. Emerg. Infect. Dis. 8, 69-73. doi: 10.3201/eid0801. 010131

Reygaert, W. C. (2018). An overview of the antimicrobial resistance mechanisms of bacteria. AIMS Microbiol. 4, 482-501. doi: 10.3934/microbiol.2018. 3.482

Richards, M. I., Michell, S. L., and Oyston, P. C. F. (2008). An intracellularly inducible gene involved in virulence and polyphosphate production in Francisella. J. Med. Microbiol. 57(Pt 10), 1183-1192. doi: 10.1099/jmm.0.2008/ 001826-0

Saha, S., Savage, P. B., and Bal, M. (2008). Enhancement of the efficacy of erythromycin in multiple antibiotic-resistant gram-negative bacterial pathogens. J. Appl. Microbiol. 105, 822-828. doi: 10.1111/j.1365-2672.2008. 03820.x

Sampson, T. R., Napier, B. A., Schroeder, M. R., Louwen, R., Zhao, J., Chin, C.Y., et al. (2014). A CRISPR-Cas system enhances envelope integrity mediating antibiotic resistance and inflammasome evasion. Proc. Natl. Acad. Sci. 111, 11163-11168. doi: 10.1073/pnas.1323025111

Sampson, T. R., Saroj, S. D., Llewellyn, A. C., Tzeng, Y. L., and Weiss, D. S. (2013). A CRISPR/Cas system mediates bacterial innate immune evasion and virulence. Nature 497, 254-257. doi: 10.1038/nature12048

Scarff, J. M., Waidyarachchi, S. L., Meyer, C. J., Lane, D. J., Chai, W., Lemmon, M. M., et al. (2019). Aminomethyl spectinomycins: a novel antibacterial chemotype for biothreat pathogens. J. Antibiot. (Tokyo) 72, 693-701. doi: 10.1038/s41429-019-0194-8

Schaenzer, A. J., and Wright, G. D. (2020). Antibiotic resistance by enzymatic modification of antibiotic targets. Trends Mol. Med. 26, 768-782. doi: 10.1016/ j.molmed.2020.05.001

Scheel, O., Hoel, T., Sandvik, T., and Berdal, B. P. (1993). Susceptibility pattern of Scandinavian Francisella tularensis isolates with regard to oral and parenteral antimicrobial agents. APMIS 101, 33-36. doi: 10.1111/j.1699-0463.1993. tb00077.x

Schmidt, H., Korfmann, G., Barth, H., and Martin, H. H. (1995). The signal transducer encoded by ampG is essential for induction of chromosomal AmpC beta-lactamase in Escherichia coli by beta-lactam antibiotics and 'unspecific' inducers. Microbiology (Reading) 141(Pt 5), 1085-1092. doi: 10.1099/13500872141-5-1085

Schmitt, D. M., Barnes, R., Rogerson, T., Haught, A., Mazzella, L. K., Ford, M., et al. (2017). The role and mechanism of erythrocyte invasion by Francisella tularensis. Front. Cell. Infect. Microbiol. 7:173. doi: 10.3389/fcimb.2017. 00173

Schunder, E., Rydzewski, K., Grunow, R., and Heuner, K. (2013). First indication for a functional CRISPR/Cas system in Francisella tularensis. Int. J. Med. Microbiol. 303, 51-60. doi: 10.1016/j.ijmm.2012. 11.004
Schwede, T., Kopp, J., Guex, N., and Peitsch, M. C. (2003). SWISS-MODEL: an automated protein homology-modeling server. Nucleic Acids Res. 31, 33813385. doi: 10.1093/nar/gkg520

Shaw, W. V. (1975). Chloramphenicol acetyltransferase from chloramphenicolresistant bacteria. Methods Enzymol. 43, 737-755. doi: 10.1016/0076-6879(75) 43141-X

Sheshko, V., Link, M., Golovliov, I., Balonova, L., and Stulik, J. (2021). Utilization of a tetracycline-inducible system for high-level expression of recombinant proteins in Francisella tularensis LVS. Plasmid 115:102564. doi: 10.1016/j. plasmid.2021.102564

Siddaramappa, S., Challacombe, J. F., Petersen, J. M., Pillai, S., Hogg, G., and Kuske, C. R. (2011). Common ancestry and novel genetic traits of Francisella novicidalike isolates from North America and Australia as revealed by comparative genomic analyses. Appl. Environ. Microbiol. 77, 5110-5122. doi: 10.1128/AEM. 00337- 11

Siddaramappa, S., Challacombe, J. F., Petersen, J. M., Pillai, S., and Kuske, C. R. (2012). Genetic diversity within the genus Francisella as revealed by comparative analyses of the genomes of two North American isolates from environmental sources. BMC Genomics 13:422. doi: 10.1186/1471-2164-13422

Siebert, C., Lindgren, H., Ferre, S., Villers, C., Boisset, S., Perard, J., et al. (2019). Francisella tularensis: FupA mutation contributes to fluoroquinolone resistance by increasing vesicle secretion and biofilm formation. Emerg. Microbes Infect. 8 , 808-822. doi: 10.1080/22221751.2019.1615848

Siebert, C., Villers, C., Pavlou, G., Touquet, B., Yakandawala, N., Tardieux, I., et al. (2020). Francisella novicida and F. philomiragia biofilm features conditionning fitness in spring water and in presence of antibiotics. PLoS One 15:e0228591. doi: 10.1371/journal.pone.0228591

Singh, S., Singh, S. K., Chowdhury, I., and Singh, R. (2017). Understanding the mechanism of bacterial biofilms resistance to antimicrobial agents. Open Microbiol. J. 11, 53-62. doi: 10.2174/1874285801711010053

Sjostedt, A., Sandstrom, G., Tarnvik, A., and Jaurin, B. (1990). Nucleotide sequence and $\mathrm{T}$ cell epitopes of a membrane protein of Francisella tularensis. J. Immunol. $145,311-317$.

Soto, E., Halliday-Simmonds, I., Francis, S., Kearney, M. T., and Hansen, J. D. (2015). Biofilm formation of Francisella noatunensis subsp. orientalis. Vet. Microbiol. 181, 313-317. doi: 10.1016/j.vetmic.2015.10.007

Soto, S. M. (2013). Role of efflux pumps in the antibiotic resistance of bacteria embedded in a biofilm. Virulence 4, 223-229. doi: 10.4161/viru. 23724

Spidlova, P., Stojkova, P., Dankova, V., Senitkova, I., Santic, M., Pinkas, D., et al. (2018). Francisella tularensis D-Ala D-Ala carboxypeptidase DacD is involved in intracellular replication and it is necessary for bacterial cell wall integrity. Front. Cell. Infect.Microbiol. 8:111. doi: 10.3389/fcimb.2018. 00111

Spratt, B. G. (1994). Resistance to antibiotics mediated by target alterations. Science 264, 388-393. doi: 10.1126/science.8153626

Sprynski, N., Valade, E., and Neulat-Ripoll, F. (2014). Galleria mellonella as an infection model for select agents. Methods Mol. Biol. 1197, 3-9. doi: 10.1007/ 978-1-4939-1261-2_1

Stephens, M. D., Hubble, V. B., Ernst, R. K., van Hoek, M. L., Melander, R. J., Cavanagh, J., et al. (2016). Potentiation of Francisella resistance to conventional antibiotics through small molecule adjuvants. Medchemcomm. 7, 128-131. doi: 10.1039/C5MD00353A

Strominger, J. L., Park, J. T., and Thompson, R. E. (1959). Composition of the cell wall of Staphylococcus aureus: its relation to the mechanism of action of penicillin. J. Biol. Chem. 234, 3263-3268. doi: 10.1016/S0021-9258(18)69662-0

Sutera, V., Caspar, Y., Boisset, S., and Maurin, M. (2014a). A new dye uptake assay to test the activity of antibiotics against intracellular Francisella tularensis. Front. Cell. Infect. Microbiol. 4:36. doi: 10.3389/fcimb.2014.00036

Sutera, V., Hoarau, G., Renesto, P., Caspar, Y., and Maurin, M. (2017). In vitro and in vivo evaluation of fluoroquinolone resistance associated with DNA gyrase mutations in Francisella tularensis, including in tularaemia patients with treatment failure. Int. J. Antimicrob. Agents 50, 377-383. doi: 10.1016/j. ijantimicag.2017.03.022

Sutera, V., Levert, M., Burmeister, W. P., Schneider, D., and Maurin, M. (2014b). Evolution toward high-level fluoroquinolone resistance in Francisella species. J. Antimicrob. Chemother. 69, 101-110. doi: 10.1093/jac/dkt321 
Taniguchi, H., Aramaki, H., Nikaido, Y., Mizuguchi, Y., Nakamura, M., Koga, T., et al. (1996). Rifampicin resistance and mutation of the rpoB gene in Mycobacterium tuberculosis. FEMS Microbiol. Lett. 144, 103-108. doi: 10.1111/ j.1574-6968.1996.tb08515.x

Thelaus, J., Lundmark, E., Lindgren, P., Sjodin, A., and Forsman, M. (2018). Galleria mellonella reveals niche differences between highly pathogenic and closely related strains of Francisella spp. Front. Cell. Infect. Microbiol. 8:188. doi: 10.3389/fcimb.2018.00188

Tlapak, H., Koppen, K., Rydzewski, K., Grunow, R., and Heuner, K. (2018). Construction of a new phage integration vector pFIV-Val for use in different Francisella Species. Front. Cell. Infect. Microbiol. 8:75. doi: 10.3389/fcimb.2018. 00075

Tomaso, H., Al Dahouk, S., Hofer, E., Splettstoesser, W. D., Treu, T. M., Dierich, M. P., et al. (2005). Antimicrobial susceptibilities of Austrian Francisella tularensis holarctica biovar II strains. Int. J. Antimicrob. Agents 26, 279-284. doi: 10.1016/j.ijantimicag.2005.07.003

Toth, M., Vakulenko, V., Antunes, N. T., Frase, H., and Vakulenko, S. B. (2012). Class A carbapenemase FPH-1 from Francisella philomiragia. Antimicrob. Agents Chemother. 56, 2852-2857. doi: 10.1128/AAC.00223-12

Urich, S. K., and Petersen, J. M. (2008). In vitro susceptibility of isolates of Francisella tularensis types A and B from North America. Antimicrob. Agents Chemother. 52, 2276-2278. doi: 10.1128/AAC.01584-07

van Hoek, M. L. (2013). Biofilms: an advancement in our understanding of Francisella species. Virulence 4, 833-846. doi: 10.4161/viru.27023

Verhoeven, A. B., Durham-Colleran, M. W., Pierson, T., Boswell, W. T., and Van Hoek, M. L. (2010). Francisella philomiragia biofilm formation and interaction with the aquatic protist Acanthamoeba castellanii. Biol. Bull. 219, 178-188. doi: 10.1086/BBLv219n2p178

Vinogradov, E., Perry, M. B., and Conlan, J. W. (2002). Structural analysis of Francisella tularensis lipopolysaccharide. Eur. J. Biochem. 269, 6112-6118. doi: 10.1046/j.1432-1033.2002.03321.x

Wang, B., and Sun, D. (2015). Detection of NDM-1 carbapenemase-producing Acinetobacter calcoaceticus and Acinetobacter junii in environmental samples from livestock farms. J. Antimicrob. Chemother. 70, 611-613. doi: 10.1093/jac/ dku405

Wang, X., Ribeiro, A. A., Guan, Z., Abraham, S. N., and Raetz, C. R. (2007). Attenuated virulence of a Francisella mutant lacking the lipid A 4'-phosphatase. Proc. Natl. Acad. Sci. U.S.A. 104, 4136-4141. doi: 10.1073/pnas.0611606104

Wang, X., Ribeiro, A. A., Guan, Z., McGrath, S. C., Cotter, R. J., and Raetz, C. R. (2006). Structure and biosynthesis of free lipid A molecules that replace lipopolysaccharide in Francisella tularensis subsp. novicida. Biochemistry 45, 14427-14440. doi: 10.1021/bi061767s
Wang, X., Ribeiro, A. A., Guan, Z., and Raetz, C. R. (2009). Identification of undecaprenyl phosphate-beta-D-galactosamine in Francisella novicida and its function in lipid A modification. Biochemistry 48, 1162-1172. doi: 10.1021/ bi802211k

Wilson, D. N., Hauryliuk, V., Atkinson, G. C., and O’Neill, A. J. (2020). Target protection as a key antibiotic resistance mechanism. Nat. Rev. Microbiol. 18, 637-648. doi: 10.1038/s41579-020-0386-z

Xu, C., Shi, W., and Rosen, B. P. (1996). The chromosomal arsR gene of Escherichia coli encodes a trans-acting metalloregulatory protein. J. Biol. Chem. 271, 24272432. doi: 10.1074/jbc.271.5.2427

Yun, J., Wang, X., Zhang, L., and Li, Y. (2017). Effects of lipid A acyltransferases on the pathogenesis of F. novicida. Microb. Pathog. 109, 313-318. doi: 10.1016/ j.micpath.2017.04.040

Zaghi, I., Gaibani, P., Campoli, C., Bartoletti, M., Giannella, M., Ambretti, S., et al. (2020). Serum bactericidal titres for monitoring antimicrobial therapy: current status and potential role in the management of multidrug-resistant Gram-negative infections. Clin. Microb. Infect. 26, 1338-1344. doi: 10.1016/j. cmi.2020.04.036

Zahedi Bialvaei, A., Rahbar, M., Hamidi-Farahani, R., Asgari, A., Esmailkhani, A., Mardani Dashti, Y., et al. (2021). Expression of RND efflux pumps mediated antibiotic resistance in Pseudomonas aeruginosa clinical strains. Microb. Pathog. 153:104789. doi: 10.1016/j.micpath.2021.104789

Zargar, A., Maurin, M., and Mostafavi, E. (2015). Tularemia, a re-emerging infectious disease in Iran and neighboring countrie. Epidemiol. Health 37:e2015011. doi: 10.4178/epih/e2015011

Zogaj, X., and Klose, K. E. (2010). Genetic manipulation of francisella tularensis. Front. Microbiol. 1:142. doi: 10.3389/fmicb.2010.00142

Zogaj, X., Wyatt, G. C., and Klose, K. E. (2012). Cyclic di-GMP stimulates biofilm formation and inhibits virulence of Francisella novicida. Infect. Immun. 80, 4239-4247. doi: 10.1128/IAI.00702-12

Conflict of Interest: The authors declare that the research was conducted in the absence of any commercial or financial relationships that could be construed as a potential conflict of interest.

Copyright (c) 2021 Kassinger and van Hoek. This is an open-access article distributed under the terms of the Creative Commons Attribution License (CC BY). The use, distribution or reproduction in other forums is permitted, provided the original author(s) and the copyright owner(s) are credited and that the original publication in this journal is cited, in accordance with accepted academic practice. No use, distribution or reproduction is permitted which does not comply with these terms. 